Accepted refereed manuscript of:

Torrealba D, Balasch JC, Criado M, Tort L, MacKenzie S \& Roher N (2018) Functional evidence for the inflammatory reflex in teleosts: A novel alpha7 nicotinic acetylcholine receptor modulates the macrophage response to dsRNA, Developmental and Comparative Immunology, 84, pp. 279-291.

DOI: $\underline{10.1016 / \mathrm{j} . \mathrm{dci} .2018 .02 .020}$

(C) 2018, Elsevier. Licensed under the Creative Commons Attribution-NonCommercialNoDerivatives 4.0 International http://creativecommons.org/licenses/by-nc-nd/4.0/ 


\title{
Functional evidence for the inflammatory reflex in teleosts: A novel $\alpha 7$ nicotinic acetylcholine receptor modulates the macrophage response to dsRNA
}

Débora Torrealba ${ }^{\mathrm{a}, \mathrm{b}, 1}$, Joan Carles Balasch ${ }^{\mathrm{b}}$, Manuel Criado ${ }^{\mathrm{c}}$, Lluís Tort ${ }^{\mathrm{b}}$, Simon Mackenzie $^{\mathrm{d}, 2}$ and Nerea Roher ${ }^{\mathrm{a}, \mathrm{b}, 2}$

\footnotetext{
${ }^{a}$ Institut de Biotecnologia i de Biomedicina (IBB), Universitat Autònoma de Barcelona, 08193 Cerdanyola del Vallès, Spain.

${ }^{\mathrm{b}}$ Departament de Biologia Cel-lular, Fisiologia Animal i Immunologia, Universitat Autònoma de Barcelona, 08193 Cerdanyola del Vallès, Spain

c Instituto de Neurociencias, Universidad Miguel Hernández-CSIC, 03550 Sant Joan d’Alacant, Spain.

${ }^{d}$ Institute of Aquaculture, University of Stirling, Stirling, FK9 4LA, United Kingdom.

${ }^{1}$ Current address: Department of Agricultural, Food \& Nutritional Science, University of Alberta, Alberta, Canada.

${ }^{2}$ Corresponding authors: Nerea Roher, telephone: (34) 935812805; fax: (34) 935812011; e-mail: nerea.roher@uab.cat and Simon Mackenzie, telephone: (44) 01786467992; fax: (44) 01786467852; e-mail: simon.mackenzie@ stir.ac.uk.
}

Key Words: $\alpha 7 \mathrm{nAChR}$, nicotine, poly(I:C), innate immunity, evolution

\begin{abstract}
Abbreviations
$\alpha 7 n A C h R$, alpha7 nicotinic acetylcholine receptor; $\alpha$-BTX: $\alpha$-bungarotoxin; ACh: acetylcholine; NIC: nicotine; poly(I:C): polyinosinic:polycytidylic acid.
\end{abstract}

\begin{abstract}
The inflammatory reflex modulates the innate immune system, keeping in check the detrimental consequences of overstimulation. A key player controlling the inflammatory reflex is the alpha 7 acetylcholine receptor $(\alpha 7 \mathrm{nAChR})$. This receptor is one of the signalling molecules regulating cytokine expression in macrophages. In this study, we characterize a novel teleost $\alpha 7 \mathrm{nAChR}$. Protein sequence analysis shows a high degree of conservation with mammalian orthologs and trout $\alpha 7 \mathrm{nAChR}$ has all the features and essential amino acids to form a fully functional receptor. We demonstrate that trout macrophages can bind $\alpha$-bungarotoxin ( $\alpha$-BTX), a competitive antagonist for $\alpha 7$ nAChRs. Moreover, nicotine stimulation produces a decrease in pro-inflammatory cytokine expression after stimulation with poly(I:C). These results suggest the presence
\end{abstract}


of a functional $\alpha 7 \mathrm{nAChR}$ in the macrophage plasma membrane. Further, in vivo injection of poly(I:C) induced an increase in serum ACh levels in rainbow trout. Our results manifest for the first time the functional conservation of the inflammatory reflex in teleosts.

\section{Introduction}

Neural signalling and its involvement in modulating innate immune responses has recently come to the fore (Tracey, 2012). Neuronal signals are rapid, directional, regional and capable of integrating diverse stimuli while inhibiting background noise. These are ideal features to monitor and modulate any complex system. Indeed, in other physiological systems, such as the circulatory, respiratory and digestive system, the main regulator of homeostasis is the nervous system. Close relationships between the nervous, endocrine and immune systems have been described and many works report dual relationships between them: neuro-immune, neuro-endocrine, and immuneendocrine (Rosas-Ballina and Tracey, 2009; Velázquez-Moctezuma et al., 2014). However, the specific influence of the nervous system on the immune system remains to be fully elucidated.

The inflammatory reflex is a neural circuit described in mammals that modulates the pro-inflammatory response to avoid the consequences of excessive activity (Tracey, 2010). This system, when activated by the presence of pathogen-associated molecular patterns (PAMPs) or damage-associated molecular patterns (DAMPs) from injured tissue, triggers action potentials through the afferent vagus nerve to the brainstem and other nuclei that control the vagus nerve response (Tracey, 2012). Efferent responses through the vagal system, also known as the cholinergic anti-inflammatory pathway, stimulate the organs of the reticuloendothelial system, including spleen, liver and the gastrointestinal tract (Tracey, 2002). The vagus nerve stimulates the splenic nerve resulting in norepinephrine release by adrenergic nerves (Rosas-Ballina et al., 2011). In turn, norepinephrine binds to and stimulates lymphocytes present in the spleen, that express choline acetyltransferase (ChAT) that is then able to synthesize acetylcholine (ACh). The lymphocyte derived ACh binds to alpha 7 nicotinic acetylcholine receptors $(\alpha 7 \mathrm{nAChR})$ present in spleen macrophages. As $\mathrm{ACh}$ is released, it is also rapidly hydrolyzed by acetylcholinesterase (AChE) present in mononuclear leukocytes such as $\mathrm{T}$ and $\mathrm{B}$ cells adding an additional level of control (Kawashima et al., 2012). ACh 
binding to $\alpha 7 \mathrm{nAChR}$ leads to the inhibition of the phosphorylation of inhibitor of NF$\kappa \mathrm{B}$ (IкB) (Yoshikawa et al., 2006), the downregulation of the activation of mitogenactivated protein kinases (MAPKs) and inhibition of the release of intracellular $\mathrm{Ca}^{2+}$ stores (Gwak et al., 2007) and the formation of a heterodimeric protein complex with Janus kinase 2 (JAK2), which activates signal transducer and activator of transcription 3 (STAT3) (de Jonge et al., 2005; Yoshikawa et al., 2006). Together, these signalling pathways lead to inhibition of pro-inflammatory cytokine release.

The $\alpha 7 \mathrm{nAChR}$ is a central component of the inflammatory reflex (Wang et al., 2003). It belongs to the superfamily of Cys-loop ligand-gated ion channels (Gallowitsch-Puerta and Tracey, 2005) and is a homo-pentamer of alpha 7 subunits activated by ligands such as ACh or nicotine (NIC) (Borovikova et al., 2000; Wang et al., 2003). The $\alpha 7 \mathrm{nAChR}$ is mainly expressed in the central and peripheral nervous systems, but it is also present in cells of the immune system including monocytes, macrophages, dendritic cells, B and $\mathrm{T}$ cells (Kawashima et al., 2007; Sato et al., 1999). Each receptor has five ACh-binding sites, that are located between adjacent subunits (Papke, 2014). The agonists ACh and NIC stimulate the $\alpha 7 \mathrm{nACh}$ receptor resulting in a dose-dependent inhibition of the release of pro-inflammatory cytokines including tumor necrosis factor alpha (TNF $\alpha$ ), interleukin 1 beta (IL-1 $\beta$ ), and interleukin 6 (IL-6) among others, as well as activating the release of anti-inflammatory cytokines such as IL-10. Initially, this modulation was thought to be a post-translational phenomenon (Borovikova et al., 2000; Kawashima and Fujii, 2004; Wang et al., 2003). However, recent studies on macrophages stimulated with LPS and polyinosinic:polycytidylic acid (poly(I:C)) indicated that modulation occurs, both at transcriptional and translational levels (Cui et al., 2013; Yang et al., 2015).

In teleosts, information regarding the inflammatory reflex is scarce and, although many of the individual protein components of the inflammatory reflex system have been identified in large scale sequencing efforts, no information related to the integrated functioning of the inflammatory reflex has been reported. As indicated above, a principal component of this regulatory system is the $\alpha 7 \mathrm{nAChR}$. Nicotinic acetylcholine receptors have been characterized in zebrafish (Danio rerio) (Zirger et al., 2003) and fugu (Takifugu rubripes) (Jones et al., 2003). Three $\alpha 7 \mathrm{nAChR}$ sequences ( $\alpha 7 \mathrm{a}, \mathrm{b}$ and c) have been described in the latter, in which the $\alpha 7$ a sequence is $1365 \mathrm{pb}$ long, coding for a protein of 454 AA. The protein is expressed in different tissues such as brain, stomach, heart, muscle and gonads (Jones et al., 2003). In zebrafish, the DNA coding 
for $\alpha 7 \mathrm{nAChR}$ subunits is $1527 \mathrm{bp}$, resulting in a protein of 509 AA. The zebrafish $\alpha 7 \mathrm{nAChR}$ has been expressed in Xenopus oocytes and characterized pharmacologically. Results show this $\alpha 7 \mathrm{nAChR}$ is activated by the typical nAChR agonists ACh, NIC and cytisine, as well as by selective $\alpha 7 \mathrm{nAChRs}$ agonists such as choline, tropane, and $4 \mathrm{OH}-$ GTS-21 (Papke et al., 2012). Additionally, transcriptomic studies in zebrafish indicate that $\alpha 7 \mathrm{nAChR}$ expression is down-regulated and $\mathrm{AChE}$ is up-regulated in brain after a viral infection, suggesting an inhibition of the anti-inflammatory pathway (Boltaña et al., 2013). Other aspects of the inflammatory reflex such as AChE or ACh levels have been characterised in mononuclear cells from tilapia spleen (Toledo-Ibarra et al., 2014). In rainbow trout (Oncorhynchus mykiss), Drescher and colleagues have cloned and characterized the $\alpha 9 \mathrm{nAChR}$ from saccular hair cells, analysing the evolution of audition in vertebrates (Drescher et al., 2004); but no information about $\alpha 7 \mathrm{nAChRs}$ is available. Here we describe, for the first time, the presence of $\alpha 7 \mathrm{nAChR}$ in rainbow trout and their ability to modulate the inflammatory response.

\section{Materials and methods}

\subsection{Animals}

Adult rainbow trout (O. mykiss), 100-120 g body weight, were held in cilindric tanks of $4.6 \mathrm{~m}^{3}$ total capacity at a density of $7 \mathrm{~kg} / \mathrm{m}^{3}$. The installations ( $4.2 \mathrm{l} / \mathrm{min}$ flow rate) worked with a recirculating chiller cooling system, UV-filter, sand filter, and biofilter, with temperature $\left(16^{\circ} \mathrm{C}\right)$ and photoperiod controlled $(12 \mathrm{~h} \mathrm{~L}: 12 \mathrm{~h} \mathrm{D})$. Freshwater was always passed through column filters to remove sediments and chlorine before entering into the system. Fish were fed with a commercial pellet at $2.0 \%$ of total body weight/day twice a day (Trouw T6 Classics 3P, Spain). Dissolved oxygen ( $<9 \mathrm{mg} / \mathrm{l}), \mathrm{pH}$ (6.0-8.5), nitrite $(<0.05 \mathrm{mg} / \mathrm{l})$, nitrate $(<1.0 \mathrm{mg} / \mathrm{l})$, and ammonia $(<0.07 \mathrm{mg} / \mathrm{l})$ were monitored regularly. All experimental protocols with animals were approved by the Ethics and Animal Welfare Committee and Biosecurity Committee of the Universitat Autònoma de Barcelona (Reference number 1555) in agreement with the International Guiding Principles for Biomedical Research Involving Animals (EU 2010/63).

\subsection{Tissue sampling, RNA extraction, $c D N A$ synthesis and RT-PCR}

Rainbow trout were sacrificed by anaesthetic overdose with MS-222 (300 mg/l, Sigma-Aldrich, USA). Brain and spleen were removed and immediately frozen in liquid 
nitrogen, and stored at $-80^{\circ} \mathrm{C}$ until use. Total RNA was extracted using TriReagent (Sigma-Aldrich) following manufacturer's instructions, including a DNase (SigmaAldrich) treatment step $\left(0.25 \mathrm{U} / \mu 1\right.$ for $500 \mathrm{ng}$ RNA, $\left.30 \mathrm{~min} 37^{\circ} \mathrm{C}\right)$. RNA concentration and quality were evaluated using the Nanodrop ND-1000 (Thermo Fisher Scientific, USA) and the Bioanalyser-2100 with the RNA 6000 Nano Kit (Agilent Technologies, USA), respectively. All the samples had a RIN higher than 7.5. cDNA was synthesized with $1000 \mathrm{ng}$ of total RNA in a final volume of $20 \mu \mathrm{l}$ using SuperScript III reverse transcriptase (Invitrogen, USA) and oligo-dT 15 primer (Promega, USA) according to the manufacturer's instructions. RT-PCR was carried out using $1 \mu \mathrm{l}$ of cDNA with specific primer pairs (Supplemental Table 1). Elongation factor 1 alpha (EF1 $\alpha)$ was used as a reference gene. PCR products were separated on $1 \%$ agarose gels stained with GelGreen (Biotium, USA).

\subsection{Rainbow trout $\alpha 7 n A C h$ receptor cloning}

The cloning of rainbow trout $\alpha 7 \mathrm{nAChR}$ was achieved by first analyzing the $\alpha 7 \mathrm{nAChR}$ nucleotide and protein sequences available in public databases (The National Center for Biotechnology Information, NCBI, and Universal Protein Resource, UniProt). Alignments of $\alpha 7 \mathrm{nAChR}$ sequences from different species were done using ClustalX v2.1 and degenerate primers were designed in conserved regions (Supplemental Table 1). Full length $\alpha 7 \mathrm{nAChR}$ was cloned from brain using 3 ' and 5 'RACE (Life Technologies, USA) following manufacturer's instructions with gene specific primers (Supplemental Table 1). PCR products were isolated with Nucleospin Gel and PCR Clean-up (Macherey-Nagel, Germany) and cloned into pGEM-T Easy Vector (Promega) in Escherichia coli DH5 $\alpha$ cells (Life Technologies) following manufacturer's instructions. Plasmid clones were isolated using the Nucleospin Plasmid QuickPure kit (Macherey-Nagel) and digested with EcoRI (Thermo Fisher Scientific). The plasmids were sequenced using SP6 and T7 primers with the sequencing kit

BigDye Terminator v3.1 Cycle Sequencing (Applied Biosystems, USA) in the sequencer 3 130xl Genetic Analyzer (Applied Biosystems).

\subsection{Domain structure and phylogenetic analysis}

The predicted amino acid sequence and domain features of $\alpha 7 \mathrm{nAChR}$ were identified and annotated with BankIt from NBCI (accession number: KT634308). The characteristic domains of the protein sequence were identified with the following 
analysis tools: Simple Modular Architecture Research Tool (SMART), Pfam, NetNglyc v1.0 server, NetPhos v2.0 server and SignalP v4.1 web-based analysis tools. The BLAST suite was used to search for nucleotide and protein sequence similarities and the retrieved sequences were aligned and analysed with ClustalX.

Algorithm approaches for the phylogenetic analysis included a Bayesian Markov Chain Monte Carlo (MCMC) analysis implemented in BEAST v2.2 and a bootstrapped maximum likelihood (ML) estimation of phylogenetic relationships between taxa using the RaxML package. Periplaneta americana was chosen as the outgroup. The MCMC analysis ran for $10^{7}$ generations, using a General Time Reversible model with gammadistributed rate variation across sites for substitution rates $(\mathrm{GTR}+\mathrm{I}+\mathrm{G})$, a relaxed lognormal molecular clock to model the branch length and the Yule model of branching. Tracer v1.6 was used to evaluate the non-discarded generations (10\% were rejected as burn-in) for convergence and mixing (sampling efficiency of parameters). The GTR+I+G ML majority rule extended consensus trees were evaluated after $10^{4}$ bootstrap replicates.

\subsection{The $\alpha 7 n A C h R$ tissue distribution}

Rainbow trout $(n=3)$ were stimulated with LPS or poly(I:C) to compare the $\alpha 7 \mathrm{nAChR}$ tissue distribution under basal and stimulated conditions. Fish were anesthetized with MS-222 and intraperitoneally (i.p.) injected with either $160 \mu 1$ of LPS $(8 \mathrm{mg} / \mathrm{kg})$ (E. coli 0111:B4, Sigma-Aldrich), $450 \mu \mathrm{l}$ of poly(I:C) $(3 \mathrm{mg} / \mathrm{kg})$ (Invivogen, USA) or sterile PBS (control) (Das et al., 2009; MacKenzie et al., 2008). After $12 \mathrm{~h}$ the animals were sacrificed by anaesthetic overdose, and brain, spleen, head kidney, posterior kidney, white muscle, red muscle, liver, intestine, heart and gills were removed and immediately frozen in liquid nitrogen and stored at $-80{ }^{\circ} \mathrm{C}$ until use. The tissues were homogenized with a Polytron PT-MB 1600 E (Kinematica, Germany). RNA extraction, cDNA and RT-PCR were performed as described above (see section 2.2) using $\alpha 7$ nAChR specific primers (Supplemental Table 1).

\subsection{Acetylcholine levels in rainbow trout serum and spleen}

Fish were anesthetized (MS-222, $50 \mathrm{mg} / \mathrm{l}$ ) and i.p. injected with either $160 \mu \mathrm{l}$ of LPS ( $8 \mathrm{mg} / \mathrm{kg}$ ), $450 \mu \mathrm{l}$ of poly(I:C) (3 mg/kg) or steril PBS (control). At different time points $(0,10,20,30,60,90,180$ and $720 \mathrm{~min}) 4$ animals for each treatment were sacrificed by anaesthetic overdose with MS-222 at $300 \mathrm{mg} / \mathrm{l}$. Blood samples were obtained and 
centrifuged at $1200 \mathrm{xg}$ for $15 \mathrm{~min}$ at $4^{\circ} \mathrm{C}$ to obtain the plasma. Spleens were removed and immediately frozen in liquid nitrogen, then all samples were stored at $-80^{\circ} \mathrm{C}$ until use. Spleens were homogenized with a Polytron PT-MB 1600 E in $400 \mu 1$ of cold PBS 1 $\%$ Triton X-100 (Sigma-Aldrich), then centrifuged at $16000 \mathrm{xg}$ for $10 \mathrm{~min}$ at $4^{\circ} \mathrm{C}$ and the supernatants were recovered. The ACh measurements were done using the Amplex Red acetylcholine assay kit (Invitrogen) following manufacturer's instructions. The results were analysed using One-way ANOVA followed by Tukey's post-hoc test (GraphPad Prism software v5, USA).

\subsection{Cell cultures}

Rainbow trout macrophages from spleen (SPM) and head kidney (HKM) were cultured as described previously (Roher et al., 2011) using DMEM $4.5 \mathrm{~g} / 1$ glucose supplemented with $10 \%(\mathrm{v} / \mathrm{v})$ heat inactivated FBS and Primocin (Invivogen) and incubated at $16{ }^{\circ} \mathrm{C}$ and $5 \% \mathrm{CO}_{2}$. The expression pattern of the $\alpha 7 \mathrm{nAChR}$ and $\alpha 9 \mathrm{nAChR}$ genes in trout macrophages was analysed by RT-PCR using monocytes/macrophages from day 1 to day 6 of differentiation. RNA extraction, first-strand cDNA synthesis and conventional PCR were performed as described above (see section 2.2).

\subsection{Phagocytosis assays}

The effects of ACh and NIC on macrophage phagocytosis were analysed by flow cytometry (FACS-Canto, Becton Dickinson). We used zymosan a glucan that mimics a fungi infection as particles to be phagocytized. For the dose-response assay, HKM cells were seeded in 12-well plates at $80 \%$ confluence. Cells were incubated with ACh (Sigma-Aldrich) at different doses $(0.1,1,10,100$ and $1000 \mu \mathrm{M}) 20 \mathrm{~min}$ before adding the zymosan FITC-conjugate (Life Technologies) at a 5:1 ratio (zymosan particle/macrophage) for 15 and $30 \mathrm{~min}$. For the time-course assay, cells were incubated with $500 \mu \mathrm{M}$ of ACh or $100 \mu \mathrm{M}$ of NIC (Sigma-Aldrich) 20 min before adding the zymosan at indicated times (5, 10 and $30 \mathrm{~min})$. After incubation, the medium was removed and cells were rinsed with PBS to eliminate non-phagocytosed zymosan particles. The macrophages were detached with TrypLE Express (Life technologies) and centrifuged at $300 x g$ for $5 \mathrm{~min}$. Pellets were resuspended in $200 \mu \mathrm{l}$ of PBS and analysed by cytometry. Both experiments were repeated in triplicate and for each sample 10,000 events were recorded. The results were analysed using One-way ANOVA followed by Tukey's post-hoc test. 


\section{9. $\alpha$-Bungarotoxin binding assay}

We used $\alpha$-bungarotoxin ( $\alpha$-BTX) to identify the presence of the $\alpha 7 \mathrm{nAChR}$ in the plasma membrane of macrophages. The $\alpha$-BTX-binding was evaluated by flow cytometry (FACS-Canto) and confocal microscopy (Zeiss LSM700, Germany). Briefly, for cytometry, HKM and SPM cells were seeded in 6-well plates at $80 \%$ confluence. For the binding assay, cells were incubated in suspension (final volume of $200 \mu \mathrm{l}$ medium). Cells were stimulated with 100,500 or $1000 \mu \mathrm{M}$ of nicotine (NIC) (SigmaAldrich) for $20 \mathrm{~min}$ and then $1.5 \mu \mathrm{g} / \mathrm{ml}$ of $\alpha$-BTX Alexa Fluor 647 conjugate $(\alpha$-BTX-AF647) (Life Technologies) was added and left for $1 \mathrm{~h}$ at room temperature. In another experiment, cells were stimulated with $20 \mu \mathrm{g} / \mathrm{ml}$ of poly(I:C) (Ruyra et al., 2015) or $10 \mu \mathrm{g} / \mathrm{ml}$ of LPS (Mackenzie et al., 2003) for $2 \mathrm{~h}$ and then $1.5 \mu \mathrm{g} / \mathrm{ml}$ of $\alpha$ BTX-AF647 (Life Technologies) was added and left for $1 \mathrm{~h}$. After each experiment, the medium was removed, cells were rinsed with PBS to remove non-bound $\alpha$-BTX and then were analysed by cytometry. To discard citotoxic effects at supra-physiological doses of NIC we performed MTT assays in HKM (data not shown). We did not observe NIC or ACh toxicity at any of the assayed concentrations. The experiments were done in triplicate and for each sample 10,000 events were recorded. The results were analysed using One-way ANOVA followed by Tukey's post-hoc test. For confocal microscopy, HKM cells were seeded in individual plates at $60 \%$ confluence. Cells were incubated in suspension with $1.5 \mu \mathrm{g} / \mathrm{ml}$ of $\alpha$-BTX for $1 \mathrm{~h}$ at room temperature. After 3 washes with PBS, cells were labelled with Hoechst $33342(10 \mu \mathrm{g} / \mathrm{ml})$. Images were analysed with Imaris software v8.1 (Bitplane AG, Switzerland).

\subsection{0. qPCR gene expression studies}

HKM cells were seeded in 6-well plates at $80 \%$ confluence. Cells were incubated with $1.5 \mu \mathrm{g} / \mathrm{ml}$ of $\alpha$-BTX for $30 \mathrm{~min}$, then $100 \mu \mathrm{M}$ of NIC was added (20 min) and finally the cells were treated with $10 \mu \mathrm{g} / \mathrm{ml}$ LPS or poly(I:C) for $12 \mathrm{~h}$. The treatments were: control, NIC, $\alpha$-BTX, LPS, NIC + LPS/poly(I:C) and $\alpha$-BTX + NIC + LPS/poly(I:C). The RNA extraction and first-strand cDNA synthesis were performed as described above (see section 2.2). The genes selected to evaluate the LPS response were: IL-1 $\beta$, TNF $\alpha$, IL-6, Chemokine (C-C Motif) Ligand 4 (CCL4), CC chemokines CK6 (CK6), MMP9, Cathelicidin 1 (CAMP 1) and Suppressor of Cytokine Signalling 3 (SOCS3). The genes selected to evaluate the poly(I:C) response were: CCL4, IL-1 $\beta$, 
IL-6, TNF $\alpha$, Type I Interferon (IFN-1), Myxovirus resistance (Mx-1), Melanoma differentiation-associated protein 5 (MDA5), Viperin-1 (vig-1), Toll like receptor-3 (TLR3), Toll like receptor-7 (TLR7) and Toll like receptor-8 (TLR8). EF1 $\alpha$ was used as a reference gene. qPCR was carried out using SYBR Green I PCR Supermix (Bio-Rad, USA), $250 \mathrm{nM}$ of primers (Supplemental Table 1) and $2.5 \mu 1$ of cDNA previously diluted (1:50 for target mRNA and 1:500 for the reference gene) in $10 \mu \mathrm{l}$ of final volume. Quantification was done according to the Livak method (Livak and Schmittgen, 2001). All samples were run in triplicate and the results were analysed using One-way ANOVA followed by Tukey's post-hoc test. Amplification efficiencies of all target genes were calculated and always were between 90-100\%. Amplification efficiencies were not included in the calculations. All qPCR analysis were performed according to MIQE guidelines (Bustin et al., 2009).

\section{Results}

\subsection{Rainbow trout $\alpha 7 n A C h$ subunit cloning and phylogeny}

The length of the rainbow trout $\alpha 7$ subunit of the nicotinic acetylcholine receptor cDNA was 2106 bp, containing a 217 bp 5'UTR, a 1763 bp ORF and an incomplete 126 bp 3'UTR. The ORF of the rainbow trout $\alpha 7 n A C h$ receptor (acc. number: KT634308) codes for a protein of 587 AA with an estimated molecular weight of $65.4 \mathrm{kDa}$. The $\alpha 7$ subunit has the main characteristics of alpha subunits of the nicotinic acetylcholine receptor. It has a 36 AA signal peptide and an extracellular domain of 210 AA including the disulfide bond (C128-C142) typical of these ligand-activated channels (Fig. 1). In the extracellular domain we also found two characteristic cysteines in the binding site (C190 - C191) that are distinctive to the $\alpha$ subunits of the nicotinic receptor family (Fig. 1). In addition, the extracellular domain contained the loops forming the ACh-binding site. Indeed, we found three loops forming the principal component of the ACh-binding site: loop A (W86 - Y93), loop B (W149 - M156), loop C (T182 - D197), and the three loops that form the complementary component: loop D (W 55- W60), loop E (K105 L119) and loop F (N161 - I165) (Fig. 1). In trout, the amino acids hypothetically in contact with ACh are: loop A: W86 and Y93; loop B: W149 and W154; loop C: Y188, C190, C191 and Y195; loop D: W55 and R57; loop E: L109, N111, E117 and L119, and loop F: E162 and D164. The loop sequences in rainbow trout were highly conserved when compared with other species of mammals (Homo sapiens and Mus 
musculus), bird (Gallus gallus) and fish (Poecilia reticulata, Esox Lucius, D. rerio, T. rubripes and Haplochromis burtoni) (Supplemental Fig. 1). Furthermore, in the extracellular domain, three putative glycosylation sites (N24, N68 and N111) were located as in other species (Gault et al., 1998; Seguela et al., 1993). The transmembrane domain contained four transmembrane regions (TM1: Y210 - L232; TM2: I240 - M261; TM3: I271 - V292 and TM4: L521 - V543). As expected, the cytoplasmic loop between TM3 and TM4 was poorly conserved compared with other vertebrate species (Supplemental Fig. 1). This region is typically less conserved and the 228 AA rainbow trout sequence was unusually longer than in other species, such as $H$. sapiens (156 AA), G. gallus (156 AA) or D. rerio (162 AA), but similar to T. rubripes (207 AA length). Finally, three putative phosphorylation sites were found in the cytoplasmic loop (S345, S429 and Y491), similarly to other species (Gault et al., 1998; Moss et al., 1996; Seguela et al., 1993) (Fig. 1). Summarizing, except for the extremely long cytoplasmic domain, the rainbow trout $\alpha 7 \mathrm{nAChR}$ sequence is highly conserved when compared with other vertebrate $\alpha 7$ sequences. Regarding the structure of the $\alpha 7 \mathrm{nAChR}$ gene, analysis of its exon-intron boundaries showed its distribution among 9 exons, while in other species, such as H. sapiens, G. gallus or D. rerio (Ensembl, 2013a, b, c; Gault et al., 1998) the gene contains 10 exons. The rainbow trout gene contains a larger first exon when compared to other species. Sequence analysis suggests that this first exon corresponds to the first and second exons of the other species, while the rest of the structure is homologous (Supplemental Fig. 2 A and 2B; Supplemental Methods).

Phylogenetic analysis demonstrated that the $\alpha 7 \mathrm{nAChR}$ in the taxa selected converged to the same topology, with branching differing in each phylogenetic estimation. $O$. mykiss shares $80 \%$ similarity in nucleotidic sequence with E. lucius, and 72\%, $71 \%$, $70 \%$ and $69 \%$ similarity to $P$. reticulate, H. burtoni, D. rerio and T. rubripes respectively (Fig. 2).

\section{2. $\alpha 7 n A C h R$ tissue distribution}

$\alpha 7 \mathrm{nAChR}$ tissue distribution was evaluated by conventional RT-PCR. Under basal conditions, the receptor was present in all tissues. The pattern of gene expression in different tissues was maintained after poly(I:C) and LPS injection, (Fig. 3A).

\subsection{LPS and poly(I:C) increase the ACh levels in plasma and spleen}


T lymphocytes are able to produce ACh in response to PAMPs, DAMPs or damaged tissue (Rosas-Ballina et al., 2011). Based on this precedent, fish were stimulated with LPS or poly $(\mathrm{I}: \mathrm{C})$ in vivo to assess whether they were able to modulate the levels of ACh in plasma and spleen in response to PAMPs. Our results show that poly(I:C) stimulates the release of $\mathrm{ACh}$ both in plasma and spleen. In plasma we observed a significant increase of ACh at 30 min (1.17 \pm 0.41 fold-change, $p<0.01)$ (Fig. 3B (i)) and in spleen at 20 and 30 min post-stimulation $(3.27 \pm 0.84$ fold-change, $p<0.01 ; 3.42 \pm 0.28$ foldchange, $p<0.01$, respectively) (Fig. 3B (ii)). The results show a similar trend in fish treated with LPS. We observed an ACh increase in plasma $(2 \pm 0.01$ fold-change, $p<0.0001) 30$ min after LPS injection (Fig. 3B (iii)). A similar result was observed in spleen, where treated animals increased ACh levels $(1.8 \pm 0.44$ fold-change, $p<0.0001)$ 180 min after the LPS treatment (Fig. 3B (iv)). These results highlight that different PAMPs can stimulate the cholinergic anti-inflammatory pathway by increasing the production of ACh.

\subsection{Gene expression of $\alpha 7 n A C h R$ and $\alpha 9 n A C h R$ in spleen and head kidney macrophages}

Next, we characterized the presence of acetylcholine receptors in rainbow trout macrophages by conventional RT-PCR. The $\alpha 9$ AChR ( $\alpha 9-$ I, $\alpha 9-$ II and $\alpha 9-$ III) had already been cloned and characterized in rainbow trout (Drescher et al., 2004) and since both $\alpha 7$ and $\alpha 9$ AChR subunits are able to bind $\alpha$-BXT, we evaluated their expression during macrophage differentiation. $\alpha 7 \mathrm{nAChR}$ was expressed throughout the whole differentiation process (Fig. 4A), $\alpha 7 \mathrm{nAChR}$ expression was observed both in head kidney and spleen derived macrophages. In contrast, $\alpha 9-$ I, $\alpha 9-$ II and $\alpha 9-$ III subunits were not expressed in head kidney and spleen macrophages (Fig. 4B). The absence of $\alpha 9 \mathrm{AChR}$ isoforms is relevant because $\alpha$-BTX is able to bind to $\alpha 7 \mathrm{nAChR}$ and $\alpha 9 \mathrm{AChR}$ as well. These results supported the use of $\alpha$-BTX as a tool to identify the presence of $\alpha 7 \mathrm{nAChR}$ in the membrane of trout macrophages since binding of $\alpha$-BTX would indicate exclusively the presence of $\alpha 7 \mathrm{nAChR}$.

\subsection{HKM and SPM bind $\alpha$-BTX and NIC decreases $\alpha-B T X$-binding}

To assess the presence of the $\alpha 7 \mathrm{nAChR}$ in the membrane of macrophages we used $\alpha$-BTX, which is an acetylcholine receptor antagonist that binds irreversibly to the $\alpha 7$ nAChR (Moss et al., 1996). As explained above, rainbow trout macrophages obtained 
from spleen and head kidney express $\alpha 7 \mathrm{nAChR}$ but not $\alpha 9 \mathrm{nAChR}$ (Fig. 4B), thus $\alpha$ BTX-binding indicates the unique presence of the $\alpha 7 \mathrm{nAChR}$ in our experimental model. In the same set of experiments, we also evaluated the effect of nicotine (an agonist of the acetylcholine receptor) on $\alpha$-BTX-binding. Firstly, we observed that HKM cells were able to bind $\alpha$-BTX $(22.7 \pm 4 \%$ of macrophages that are positive to $\alpha$-BTX, $p<0.0001$ ) (Fig. 5A (i)) and secondly NIC was able to decrease $\alpha$-BTX-binding in a dose-dependent manner (e.g. $12.6 \pm 1.5 \%$ at $500 \mu \mathrm{M}$ of NIC, $p<0.0001$ ). The partial inhibition of $\alpha$-BTX by NIC could be due to unknown NIC metabolism activities that could provoked a decrease in the NIC availability or could be due to unknown ligandreceptor trafficking events. Also, SPM cells were able to bind $\alpha$-BTX $(34.9 \pm 0.5 \% \alpha$ BTX-binding, $p<0.0001$ ) (Fig. 5A (ii)) and the lowest NIC concentration decreased $\alpha$ BTX-binding in these cells $(19.1 \pm 10 \%, p<0.01)$. At least two different functional populations of macrophages (M1 and M2) have been described by different authors (see Wiegertjes et al., 2016 for a review). Our $\alpha$-BTX binding results indicate that probably only a particular subpopulation of HKM or SPM express $\alpha 7 \mathrm{nAChR}$ and is able to bind $\alpha-\mathrm{BTX}(22.7 \pm 4 \%$ of HKM and $34.9 \pm 0.5 \%$ of SPM are able to bind $\alpha-\mathrm{BTX})$.

Confocal microscopy and 3D reconstruction images enabled the visualization of $\alpha$ BTX-binding to the membrane of HKM (Fig. 5B (i - iv)). Additionally, we observed that pre-stimulation of the HKM cells with poly(I:C) increased $\alpha$-BTX-binding $(47.5 \pm$ $6.4 \%$ and $32.8 \pm 3.4 \% \alpha$-BTX-binding in cells stimulated with or without poly(I:C) respectively, $p<0.05$ ) (Fig. 5C (i)). In contrast, this phenomenon was not observed in cells stimulated with LPS (Fig. 5C (ii)).

\subsection{ACh and NIC do not modulate phagocytosis in HKM}

Phagocytosis is a key function of macrophages (Secombes and Fletcher, 1992). To explore whether ACh and NIC could modulate phagocytosis in fish macrophages we stimulated HKM with ACh or NIC before incubation with labelled zymosan. Note we used HKM instead of SPM because the yield and the life span under cell culture conditions was greater in HKM. Results showed that ACh and NIC were not able to modulate phagocytic activity in HKM (Fig. 6A). In dose-response assays our results indicated that ACh even at supra-physiological concentrations did not have significant effects on phagocytosis $(61 \pm 11 \%$ control cells and $60 \pm 8 \%$ cells treated with 1000 $\mu \mathrm{M}$ of ACh, respectively) (Fig. 6A). Regarding time-course assays we did not observe significant differences in phagocytic activity at different time points. For example: at 
10 min: $50.8 \pm 2.3 \%$ zymosan cells, $53.8 \pm 6.5 \%$ cells treated with ACh and $57.7 \pm$ $12.7 \%$ cells treated with NIC; at 15 min: $60.0 \pm 3.7 \%$ zymosan cells, $59.3 \pm 6.2 \%$ cells treated with ACh and 60.1 $\pm 2 \%$ cells treated with NIC; (Fig. 6B).

\subsection{NIC modulates the expression of immune response genes after stimulation with $\operatorname{poly}(I: C)$}

A set of experiments were designed aiming to describe the basis of the macrophage response during the inflammatory reflex. We tested combinations of NIC, PAMPs and $\alpha$-BTX. Our results showed, that NIC inhibited the increase of the antiviral gene expression induced by poly(I:C). Antiviral genes such as, IFN-1, Mx-1, CCL4, CK6 and vig-1 were down-regulated by NIC (e.g. Mx-1: $25 \pm 4$ fold change after poly(I:C) treatment and $8 \pm 11$ fold change after NIC + poly(I:C) treatment, $p<0.001)$. We also assessed the expression of different toll-like receptors such as, TLR3 and TLR8 and the results showed that NIC was also able to down-regulate TLR3 expression $(2.65 \pm 0.5$ fold change after poly(I:C) treatment and $1.5 \pm 0.3$ fold change after NIC + poly(I:C), $p<0.01$ ), the same trend for TLR8 expression was observed without significant differences (Fig. 7).

In parallel, we observed that in cells pre-treated with $\alpha$-BTX the effects of NIC were attenuated (e.g. Mx-1: $25 \pm 7$ fold change in $\alpha$-BTX + NIC + poly(I:C) treated cells and TLR3: $2.1 \pm 0.1$ fold change in $\alpha$-BTX + NIC + poly(I:C) treated cells, $p<0.001)$ (Fig. 7). These results suggest a competition between $\alpha$-BTX and NIC for the binding site. However, when we evaluated the gene expression of pro-inflammatory cytokines such as, TNF $\alpha$, IL-6 and IL-1 $\beta$ we did not find any effect of NIC (data not shown). As well, the expression of genes such as, TNF $\alpha$, IL-6, IL1- $\beta$, CCL4, CK6, CAMP1, SOCS3, MMP9 were not modulated by NIC in cells treated with LPS (Supplemental Fig. 3).

\section{Discussion}

The $\alpha 7 \mathrm{nAChR}$ is a key player controlling the inflammatory reflex. This receptor is one of the signalling molecules regulating cytokine expression in macrophages through the binding of ACh. In rainbow trout, the amino acids hypothetically in contact with ACh are highly conserved when compared with other vertebrate species (e.g. $H$. sapiens, G. gallus, D. rerio and T. rubripes) (Supplemental Fig. 1). The amino acids contributing to the ACh-binding site are organized in six loops (Corrienger et al., 2000). 
When we compared the ACh-binding site of trout and human sequences we observed only two different residues in loop D (Q57 $\rightarrow$ R57) and in loop E (Q117 $\rightarrow$ E117). However, these amino acids were not always conserved in other species (Supplemental Fig. 1). Therefore, the differences between these amino acids should not affect the ability of $\alpha 7 \mathrm{nAChR}$ to bind ACh. Also, the residues involved in $\alpha$-BTX binding are conserved (Sine, 2002). In fact, a phenylalanine and two tyrosines in loop C are essential to maintain high affinity for $\alpha$-BTX (Huang et al., 2013; Sine et al., 2013). These residues are present in the rainbow trout sequence (F187, Y188 and Y195) (Fig. $8 \mathrm{~A}$ ), indicating that the receptor would be able to bind $\alpha$-BTX with high affinity.

This prediction was confirmed by our experiments in vitro. Trout macrophages did bind $\alpha$-BTX, and this binding was partially inhibited by NIC. This result has been previously described in human macrophages, where incubation with NIC before the addition of $\alpha$-BTX, provoked a decrease in neurotoxin binding (Cui et al., 2013; Wang et al., 2003). The NIC concentrations used in our study were similar to those of other studies (Wang et al., 2003; Borovikova et al., 2000) and are considered supraphysiological doses and are mainly used as a tool to understand the inflammatory reflex.

Additionally, the stimulation of trout macrophages with poly(I:C), before $\alpha$-BTX addition, induced a significant increase in $\alpha$-BTX-binding which was not observed in cells treated with LPS. This indicates that stimulation with poly(I:C) increased the presence of $\alpha 7 \mathrm{nAChR}$ in the plasma membrane. In mammals LPS induces an increase in $\alpha 7 \mathrm{nAChR}$ in the membrane, enhancing $\alpha$-BTX -binding $9 \mathrm{~h}$ after stimulation (Corrienger et al., 2000). Our results in trout show that LPS can stimulate $\alpha 7 \mathrm{nAChR}$ gene expression $12 \mathrm{~h}$ after the stimulation, however it was not able to increase $\alpha$-BTXbinding. These results would suggest that LPS-driven signalling requires more time to induce an increase in $\alpha 7 \mathrm{nAChR}$ at the membrane in comparison with poly(I:C).

To see if we could obtain active receptor channels in vivo, we injected RNA coding for the trout $\alpha 7 \mathrm{nAChR}$ subunit into Xenopus oocytes. However, this failed to yield a functional nACh receptor (data not shown). This was the case even when the RNA was co-injected with the human chaperone resistance-to-cholinesterase 3 (RIC-3), which is essential for the correct folding of the receptor (Bennett et al., 2012; Castelan et al., 2008). An explanation for this lack of activity could be that other $\alpha 7 \mathrm{nAChR}$ isoforms exist and they are, in fact, the active ones. In chicken and mammals $\alpha 7$ single genes have been described while in fugu at least 3 different $\alpha 7$ sequences were found but no functional experiments were performed for any of these isoforms (Jones et al., 2003). In 
an in-silico analysis we found a non-annotated protein sequence (CDQ72725) with high similarity to our receptor sequence (Supplemental Fig. 4A and 4B). However, we did not find any evidence of its gene expression in trout macrophages or tissues (data not shown). Our hypothesis is that this sequence (CDQ72725) could be an alpha7 paralog that has evolved after genome duplication as a pseudogene.

Another relevant factor concerning the lack of expression of trout $\alpha 7 \mathrm{nAChR}$ observed in Xenopus, is the unusual length of the cytoplasmic region between the TM3 and TM4 segments. Note that this region is considered to be crucial for the correct expression, folding and trafficking of $\alpha 7 \mathrm{nAChR}$ to the plasma membrane, as tested using mutants of rat $\alpha 7 n$ AChR (Castelán et al., 2007; Valor et al., 2002) (Fig. 8B).

Different PAMPs stimulated the expression of the $\alpha 7 \mathrm{nAChR}$ in various trout tissues in vivo. However, $\alpha 7 \mathrm{nAChR}$ was mainly expressed in brain which is consistent with the function of these receptors in the central nervous system modulating distinct neural functions (Lindstrom, 1997). In trout the highest expression after PAMPs stimulation was observed in the posterior kidney, head kidney, liver and muscle. There is limited information related to the tissue distribution of the nicotinic receptors, because characterization studies have focused mainly on brain and immune cells ( $\mathrm{T}$ cells, B cells, monocytes, macrophages and dendritic cells) (Kawashima et al., 2007; Sato et al., 1999). However, the $\alpha 7 \mathrm{nAChR}$ (isoform $\alpha 7 \mathrm{a}$ ) in fugu has been detected in brain, gills, gonads, stomach, heart and muscle (Jones et al., 2003), and the rt- $\alpha 9 \mathrm{nAChR}$ (isoform I, II and III) in tissues such as, brain, spleen, liver, pituitary gland and retina (Drescher et al., 2004). We detected trout $\alpha 7 \mathrm{nAChR}$ in macrophages from spleen and head kidney, consistent with what has been described in mammals (Borovikova et al., 2000; Cui et al., 2013; van der Zanden et al., 2009).

Our results showed that both poly(I:C) and LPS increased plasma and spleen ACh levels very rapidly. ACh has been detected in blood and plasma of different mammalian species such as human, rat, sheep, rabbit and horse ranging from $33 \pm 10 \mathrm{pg} / \mathrm{ml}$ to $2254 \pm 231 \mathrm{pg} / \mathrm{ml}$ (Kawashima and Fujii, 2004; Kawashima et al., 2012). The basal levels described in Nile tilapia mononuclear cells were $23.55 \pm 6.03 \mu \mathrm{M}\left(3358 \times 10^{3}\right.$ pg/ml) (Toledo-Ibarra et al., 2014).

Neither NIC nor ACh could modulate phagocytosis in trout macrophages in agreement with previous studies in human monocytes and macrophages (Neumann et al., 2007). However, our results indicate that NIC modulates the immune response after stimulation with poly(I:C), but not with LPS at the concentration and time points tested. 
In mammals the activation of the $\alpha 7 \mathrm{nAChR}$ with poly(I:C) and LPS induces a decrease of pro-inflammatory cytokines such as TNF $\alpha$, IL-1 $\beta$, IL-6 and IL-8, both at mRNA and protein levels (Borovikova et al., 2000; Cui et al., 2013; Wang et al., 2003). We observed a modulation of the expression of genes involved in the antiviral response (IFN-1, Mx-1, CCL4, vig-1 and TLR3), but not those involved in the pro-inflammatory response (TNF $\alpha$, IL-6 and IL-1 $)$ ) after a stimulation with poly(I:C). The regulation observed occurs via the $\alpha 7 \mathrm{nAChR}$, because the addition of a specific antagonist $(\alpha-$ BTX) produces a decrease in the NIC effect, thus increasing the gene expression of antiviral genes.

The specific effects of poly(I:C) compared to those of LPS may occur because fish are much less sensitive to LPS than mammals (Mackenzie et al., 2003). The absence of LPS co-receptor molecules such as MD2 and CD14 in the fish genome might explain this (Sepulcre et al., 2009). Consequently, in fish it would not be imperative to activate additional homeostatic control to prevent overstimulation of the immune response by LPS. In contrast, in mammals LPS can cause septic shock and the system should be under tight control (Vincent et al., 2013). In contrast, the antiviral response through TLR3 is highly conserved in vertebrates and orthologs of mammalian viral receptors have been reported in different fish species, such as trout, zebrafish and salmon (Phelan et al., 2005; Rodriguez et al., 2005; Strandskog et al., 2008).

Our results demonstrate for the first time the functional conservation of the inflammatory reflex in teleosts. The novel teleost $\alpha 7 \mathrm{nAChR}$ is found in macrophages modulating the innate immune response, as is found in mammals.

\section{Acknowledgments}

We would like to thank Dr. Caceres and Dr. Castellanos for technical assistance in preparing genomic DNA and Rosemary Thwaite for English correction of the manuscript. This work was supported by grants from the Spanish Ministry of Science, European funding and AGAUR funds to NR (AGL2012-33877, MINECO/FEDER and 2014SGR-345). DT was supported by a CONICYT PhD fellowship, Chile (72120133, 2011) and NR is supported by the Ramón y Cajal program (RYC-2010-06210, 2010, MINECO).

\section{Supplementary data}


Supplementary data related to this article can be found at

\section{References}

Bennett, H.M., Lees, K., Harper, K.M., Jones, A.K., Sattelle, D.B., Wonnacott, S., Wolstenholme, A.J., 2012. Xenopus laevis RIC-3 enhances the functional expression of the $C$. elegans homomeric nicotinic receptor, ACR-16, in Xenopus oocytes. J. Neurochem. 123, 911-918.

Boltaña, S., Rey, S., Roher, N., Vargas, R., Huerta, M., Huntingford, F.A., Goetz, F.W., Moore, J., Garcia-Valtanen, P., Estepa, A., Mackenzie, S., 2013. Behavioural fever is a synergic signal amplifying the innate immune response. Proc. Biol. Sci. 280, 20131381.

Borovikova, L.V., Ivanova, S., Zhang, M., Yang, H., Botchkina, G.L., Watkins, L.R., Wang, H., Abumrad, N., Eaton, J.W., Tracey, K.J., 2000. Vagus nerve stimulation attenuates the systemic inflammatory response to endotoxin. Nature 405, 458-462.

Castelan, F., Castillo, M., Mulet, J., Sala, S., Sala, F., Dominguez Del Toro, E., Criado, M., 2008. Molecular characterization and localization of the RIC-3 protein, an effector of nicotinic acetylcholine receptor expression. J. Neurochem. 105, 617-627.

Castelán, F., Mulet, J., Aldea, M., Sala, S., Sala, F., Criado, M., 2007. Cytoplasmic regions adjacent to the M3 and M4 transmembrane segments influence expression and function of alpha7 nicotinic acetylcholine receptors. A study with single amino acid mutants. J. Neurochem. 100, 406-415.

Corrienger, P.J., Le Novère, N., Changeux, J.P., 2000. Nicotinic receptors at the amino acids level. Annu. Rev. Pharmacol. Toxicol. 40, 431-458.

Cui, W.Y., Zhao, S., Polanowska-Grabowska, R., Wang, J., Wei, J., Dash, B., Chang, S.L., Saucerman, J.J., Gu, J., Li, M.D., 2013. Identification and characterization of poly(I:C)-induced molecular responses attenuated by nicotine in mouse macrophages. Mol. Pharmacol. 83, 61-72.

Das, B.K., Ellis, A.E., Collet, B., 2009. Induction and persistence of Mx protein in tissues, blood and plasma of Atlantic salmon parr, Salmo salar, injected with poly I:C. Fish Shellfish Immunol. 26, 40-48.

de Jonge, W.J., van der Zanden, E.P., The, F.O., Bijlsma, M.F., van Westerloo, D.J., Bennink, R.J., Berthoud, H.R., Uematsu, S., Akira, S., van den Wijngaard, R.M., Boeckxstaens, G.E., 2005. Stimulation of the vagus nerve attenuates macrophage activation by activating the Jak2-STAT3 signaling pathway. Nat. Immunol. 6, 844-851.

Drescher, D.G., Ramakrishnan, N.A., Drescher, M.J., Chun, W., Wang, X., Myers, S.F., Green, G.E., Sadrazodi, K., Karadaghy, A.A., Poopat, N., Karpenko, A.N., Khan, K.M., Hatfield, J.S., 2004. Cloning and characterization of alpha9 subunits of the nicotinic 
acetylcholine receptor expressed by saccular hair cells of the rainbow trout (Oncorhynchus mykiss). Neuroscience 127, 737-752.

Ensembl, 2013a. Danio rerio. Ensembl Genome Browser. [online] http://www.ensembl.org/Danio_rerio/Transcript/Summary?db=core;g=ENSDARG0000 170101702;r=7:53371605-53400001;t=ENSDART00000171463. Accessed on February 2, 2013.

Ensembl, 2013b. Gallus gallus. Ensembl Genome Browser. [online] http://www.ensembl.org/Gallus_gallus/Gene/Summary?db=core;g=ENSGALG0000000 4096;r=10:6156717-6199170;t=ENSGALT00000006519. Accessed on February 2, 2013.

Ensembl, 2013c. Takifugu rubripes. Ensembl Genome Browser. [online] http://www.ensembl.org/Takifugu_rubripes/Gene/Summary?db=core;g=ENSTRUG000 00016472;r=scaffold_1:2525614-2531987. Accessed on February 2, 2013.

Gallowitsch-Puerta, M., Tracey, K.J., 2005. Immunologic role of the cholinergic antiinflammatory pathway and the nicotinic acetylcholine alpha 7 receptor. Ann. N. Y. Acad. Sci. 1062, 209-219.

Gault, J., Robinson, M., Berger, R., Drebing, C., Logel, J., Hopkins, J., Moore, T., Jacobs, S., Meriwether, J., Chio, M., Kim, E., Walton, K., Buiting, K., Davis, A., Bresee, C., Freedman, R., Leonard, S., 1998. Genomic organization and partial duplication of the human alpha7 neuronal nicotinic acetylcholine receptor gene (CHRNA7). Genomics 52, 173-185.

Gwak, Y.S., Kang, J., Leem, J.W., Hulsebosch, C.E., 2007. Spinal AMPA receptor inhibition attenuates mechanical allodynia and neuronal hyperexcitability following spinal cord injury in rats. J. Neurosci. Res. 85, 2352-2359.

Huang, S., Li, S.X., Bren, N., Cheng, K., Gomoto, R., Chen, L., Sine, S.M., 2013. Complex between alpha-bungarotoxin and an alpha7 nicotinic receptor ligand-binding domain chimaera. Biochem. J. 454, 303-310.

Jones, A.K., Elgar, G., Sattelle, D.B., 2003. The nicotinic acetylcholine receptor gene family of the pufferfish, Fugu rubripes. Genomics 82, 441-451.

Kawashima, K., Fujii, T., 2004. Expression of non-neuronal acetylcholine in lymphocytes and its contribution to the regulation of immune function. Front. Biosci. 9, 2063-2085.

Kawashima, K., Fujii, T., Moriwaki, Y., Misawa, H., 2012. Critical roles of acetylcholine and the muscarinic and nicotinic acetylcholine receptors in the regulation of immune function. Life Sci. 91, 1027-1032.

Kawashima, K., Yoshikawa, K., Fujii, Y.X., Moriwaki, Y., Misawa, H., 2007. Expression and function of genes encoding cholinergic components in murine immune cells. Life Sci. 80, 2314-2319. 
Lindstrom, J., 1997. Nicotinic acetylcholine receptors in health and disease. Mol. Neurobiol. 15, 193-222.

Livak, K.J., Schmittgen, T.D., 2001. Analysis of relative gene expression data using real-time quantitative PCR and the 2(-Delta Delta C(T)) method. Methods 25, 402-408.

MacKenzie, S., Balasch, J.C., Novoa, B., Ribas, L., Roher, N., Krasnov, A., Figueras, A., 2008. Comparative analysis of the acute response of the trout, O. mykiss, head kidney to in vivo challenge with virulent and attenuated infectious hematopoietic necrosis virus and LPS-induced inflammation. BMC genomics 9, 141-162.

Mackenzie, S., Planas, J.V., Goetz, F., 2003. LPS-stimulated expression of a tumor necrosis factor-alpha mRNA in primary trout monocytes and in vitro differentiated macrophages. Dev. Comp. Immunol. 27, 393-400.

Moss, S.J., McDonald, B.J., Rudhard, Y., Schoepfer, R., 1996. Phosphorylation of the predicted major intracellular domains of the rat and chick neuronal nicotinic acetylcholine receptor a7 subunit by CAMP-dependent protein kinase. Neuropharmacology 35, 1023-1028.

Neumann, S., Razen, M., Habermehl, P., Meyer, C.U., Zepp, F., Kirkpatrick, C.J., Wessler, I., 2007. The non-neuronal cholinergic system in peripheral blood cells: effects of nicotinic and muscarinic receptor antagonists on phagocytosis, respiratory burst and migration. Life Sci. 80, 2361-2364.

Papke, R.L., 2014. Merging old and new perspectives on nicotinic acetylcholine receptors. Biochem. Pharmacol. 89, 1-11.

Papke, R.L., Ono, F., Stokes, C., Urban, J.M., Boyd, R.T., 2012. The nicotinic acetylcholine receptors of zebrafish and an evaluation of pharmacological tools used for their study. Biochem. Pharmacol. 84, 352-365.

Phelan, P.E., Mellon, M.T., Kim, C.H., 2005. Functional characterization of full-length TLR3, IRAK-4, and TRAF6 in zebrafish (Danio rerio). Mol. Immunol. 42, 1057-1071.

Rodriguez, M.F., Wiens, G.D., Purcell, M.K., Palti, Y., 2005. Characterization of Tolllike receptor 3 gene in rainbow trout (Oncorhynchus mykiss). Immunogenetics 57, 510519.

Roher, N., Callol, A., Planas, J.V., Goetz, F.W., MacKenzie, S.A., 2011. Endotoxin recognition in fish results in inflammatory cytokine secretion not gene expression. Innate Immun. 17, 16-28.

Rosas-Ballina, M., Olofsson, P.S., Ochani, M., Valdés-Ferrer, S., Levine, Y.A., Reardon, C., Tusche, M.W., Pavlov, V.A., Andersson, U., Chavan, S., Mak, T.W., Tracey, K.J., 2011. Acetylcholine-synthesizing T cells relay neural signals in a vagus nerve circuit. Science 334, 98-101.

Rosas-Ballina, M., Tracey, K.J., 2009. The neurology of the immune system: neural reflexes regulate immunity. Neuron 64, 28-32. 
Ruyra, A., Torrealba, D., Morera, D., Tort, L., MacKenzie, S., Roher, N., 2015. Zebrafish liver (ZFL) cells are able to mount an anti-viral response after stimulation with Poly (I:C). Comp. Biochem. Physiol. B Biochem. Mol. Biol. 182, 55-63.

Sato, K., Fujii, T., Watanabe, Y., Yamada, S., Ando, T., Kazuko, F., Kawashima, K., 1999. Diversity of mRNA expression for muscarinic acetylcholine receptor subtypes and neuronal nicotinic acetylcholine receptor subunits in human mononuclear leukocytes and leukemic cell lines. Neurosci. Lett. 266, 17-20.

Secombes, C., Fletcher, T.C., 1992. The role of phagocytes in the protective mechanisms of fish. Annu. Rev. Fish Dis. 2, 53-71.

Seguela, P., Wadiche, J., Dineley-Miller, K., Dani, J.A., Patrick, J.W., 1993. Molecular cloning, functional properties, and distribution of rat brain alpha7: A nicotinic cation channel higly permeable to calcium. J. Neurosci. 13, 596-604.

Sepulcre, M.P., Alcaraz-Perez, F., Lopez-Munoz, A., Roca, F.J., Meseguer, J., Cayuela, M.L., Mulero, V., 2009. Evolution of lipopolysaccharide (LPS) recognition and signaling: fish TLR4 does not recognize LPS and negatively regulates NF-kappaB activation. J. Immunol. 182, 1836-1845.

Sine, S.M., 2002. The nicotinic receptor ligand binding domain. J. Neurobiol. 53, 431446.

Sine, S.M., Huang, S., Li, S.X., daCosta, C.J., Chen, L., 2013. Inter-residue coupling contributes to high-affinity subtype-selective binding of alpha-bungarotoxin to nicotinic receptors. Biochem. J. 454, 311-321.

Strandskog, G., Skjaeveland, I., Ellingsen, T., Jorgensen, J.B., 2008. Double-stranded RNA- and CpG DNA-induced immune responses in Atlantic salmon: comparison and synergies. Vaccine 26, 4704-4715.

Toledo-Ibarra, G.A., Díaz-Resendiz, K.J., Pavón, L., Girón-Pérez, M.I., 2014. Cholinergic activity in mononuclear cells of Nile Tilapia (Oreochromis niloticus) fish. Adv. Neuroimmune Biol. 5, 229-234.

Tracey, K.J., 2002. The inflammatory reflex. Nature 420, 853-859.

Tracey, K.J., 2010. Understanding immunity requires more than immunology. Nat. Immunol. 11, 561-564.

Tracey, K.J., 2012. Immune cells exploit a neural circuit to enter the CNS. Cell 148, 392-394.

Valor, L., Mulet, J., Sala, F., Sala, S., Ballesta, J.J., Criado, M., 2002. Role of the large cytoplasmic loop of the alpha7 neuronal nicotinic acetylcholine receptor subunit in receptor expression and function. Biochemistry 41, 7931-7938. 
van der Zanden, E.P., Snoek, S.A., Heinsbroek, S.E., Stanisor, O.I., Verseijden, C., Boeckxstaens, G.E., Peppelenbosch, M.P., Greaves, D.R., Gordon, S., De Jonge, W.J., 2009. Vagus nerve activity augments intestinal macrophage phagocytosis via nicotinic acetylcholine receptor alpha4beta2. Gastroenterology 137, 1029, 1039

Velázquez-Moctezuma, J., Domínguez-Salazar, E., Gómez-González, B., 2014. Beyond the borders: the gates and fences of neuroimmune interaction. Front. Integr. Neurosci. 8, $1-2$.

Vincent, J.L., Opal, S.M., Marshall, J.C., Tracey, K.J., 2013. Sepsis definitions: time for change. The Lancet 381, 774-775.

Wang, H., yu, M., Ochani, M., Amella, C., Tanovic, M., Susarla, S., Li, J., Czura, C., Tracey, K.J., 2003. Nicotinic acetylcholine receptor alpha7 subunit is an essential regulator of inflammation. Nature 421, 384-388.

Wiegertjes, G.F., Wentzel, A.S., Spaink, H.P., Elks, P.M., Fink, I.R., 2016. Polarization of immune responses in fish: The 'macrophages first' point of view. Molecular immunology 69, 146-156.

Yang, Y.H., Li, D.L., Bi, X.Y., Sun, L., Yu, X.J., Fang, H.L., Miao, Y., Zhao, M., He, X., Liu, J.J., Zang, W.J., 2015. Acetylcholine inhibits LPS-induced MMP-9 production and cell migration via the alpha7 nAChR-JAK2/STAT3 pathway in RAW264.7 cells. Cell Physiol. Biochem. 36, 2025-2038.

Yoshikawa, H., Kurokawa, M., Ozaki, N., Nara, K., Atou, K., Takada, E., Kamochi, H., Suzuki, N., 2006. Nicotine inhibits the production of proinflammatory mediators in human monocytes by suppression of I-kappaB phosphorylation and nuclear factorkappaB transcriptional activity through nicotinic acetylcholine receptor alpha7. Clin. Exp. Immunol. 146, 116-123.

Zirger, J.M., Beattie, C.E., McKay, D.B., Thomas Boyd, R., 2003. Cloning and expression of zebrafish neuronal nicotinic acetylcholine receptors. Gene Expr. Patterns $3,747-754$. 


\section{Figure Legends}

Figure 1. Coding sequence of rainbow trout $\alpha 7 \mathrm{nAChR}$ subunit. Protein and nucleotide sequences. AA and nucleotide numbering is shown in the right margin. The signal peptide (red underline), the cysteines $(\diamond)$ that form a disulfide bond in the binding site and the putative glycosylation (•) and phosphorylation sites ( $\boldsymbol{(})$ are shown. Black underline shows the ACh-binding site loops (A, B, C, D, E and F). The Cys-loop is indicated with a yellow underline. Grey underline marks the transmembrane regions (TM1 - TM4).

Figure 2. Phylogenetic relationships of rainbow trout $\alpha 7 \mathrm{nACh}$ receptor with other species. Branching values are the maximum likelihood percentage of majority rule extended consensus bootstrapped trees and Bayesian posterior probabilities, respectively. Periplaneta americana (cockroach, JX466891.1) was chosen as the outgroup. The bar indicates the phylogenetic distance. Sequences accession number: $O$. mykiss (rainbow trout): KT634308, E. lucius (northern pike): XM_010899081.2, P. reticulate (guppy): XM_008422486.1, H. burtoni (Burton's haplo): XM_005927614.1, T. rubripes (fugu): XM_003969344.1, D. rerio (zebrafish): XM_009294051.1, G. gallus (chicken): NM_204181.2, M. musculus (mouse): AF225980.1, H. sapiens (human): AF385585.1.

Figure 3. (A) Rainbow trout $\alpha 7 \mathrm{nAChR}$ tissue distribution. Receptor distribution in animals treated with LPS, poly(I:C) or PBS were analysed by RT-PCR. Abbreviations: B: brain; SP: spleen; HK: head kidney; PK: posterior kidney; WM: white muscle; RM: red muscle; L: liver; I: intestine; G: gills and H: heart. (B) ACh levels in rainbow trout plasma and spleen homogenate after poly(I:C) and LPS in vivo stimulation. ACh levels after a i.p. injection of poly(I:C) and LPS. The samples of plasma (i and iii) and spleen (ii and iv) were taken at different times (0, 10, 20, 30, 60, 90, 180 and $720 \mathrm{~min}$ ). The ACh measurements were done using the Amplex Red acetylcholine assay kit. Foldchange was calculated in reference to the control. Differences were analysed using Oneway ANOVA followed by Tukey's post-hoc test; data represent mean $\pm \operatorname{SD}(n=4)$. Significant differences with respect to control **, $p<0.01 ; * * *, p<0.0001$. 
Figure 4. $\alpha 7 n A C h R$ and $\alpha 9 n A C h R$ gene expression in SPM and HKM. (A) The $\alpha 7$ nAChR gene expression from day 1 to day 6 of differentiation was analysed by RTPCR in HKM. (B) Gene expression of the $\alpha 7 \mathrm{nAChR}$ and the $\alpha 9 \mathrm{nAChR}$ I, II and III subunits was analysed by qPCR at day 5 .

Figure 5. $\alpha$-BTX-binding in rainbow trout macrophages. (A) $\alpha$-BTX-binding in rainbow trout macrophages. (i) HKM were incubated with 100,500 or $1000 \mu \mathrm{M}$ of NIC $20 \mathrm{~min}$ before adding $1.5 \mu \mathrm{g} / \mathrm{ml} \alpha$-BTX-AF647 for $1 \mathrm{~h}$. (ii) SPM were incubated with $100 \mu \mathrm{M}$ of NIC $20 \mathrm{~min}$ before adding $1.5 \mu \mathrm{g} / \mathrm{ml} \alpha$-BTX for $1 \mathrm{~h}$. (B) Confocal microscopy images of $\alpha$-BTX-binding (red) in HKM. Cells were incubated $1 \mathrm{~h}$ with 1.5 $\mu \mathrm{g} / \mathrm{ml}$ of $\alpha$-BTX-AF647. Hoechst (blue) was used for nuclei labelling. (i) Control cells, (ii) HKM cells at $1 \mathrm{~h}$ after addition of $\alpha$-BTX-AF647, (iii) 3D image reconstruction of a whole cell and (iv) longitudinal stack of the cell showing the nuclei. (C) The $\alpha$-BTXbinding in HKM after a stimulation with (i) poly(I:C) and (ii) LPS. Differences were analysed using One-way ANOVA followed by Tukey's post-hoc test. Data represent means $\pm \mathrm{SD}(n=3)$. Significant differences with respect to $\alpha$-BTX: *, $p<0.05$; **, $p<0.01 ; * * *, p<0.001$.

Figure 6. Effects of ACh and NIC on the phagocytosis of zymosan by HKM. (A) Dose-response analysis. Cells were incubated with 0.1 to $1000 \mu \mathrm{M}$ of ACh for $20 \mathrm{~min}$ before the addition of zymosan for 15 and $30 \mathrm{~min}$. (B) Time-course analysis. Cells were incubated with $500 \mu \mathrm{M}$ of $\mathrm{ACh}$ or $100 \mu \mathrm{M}$ of NIC $20 \mathrm{~min}$ before the addition of zymosan for 5, 10 and $30 \mathrm{~min}$. Data represent the means $\pm \operatorname{SD}(n=3)$.

Figure 7. Gene expression analysis in HKM cells treated with NIC and $\alpha$-BTX prior to stimulation with poly(I:C). Gene expression was analysed by qPCR in HKM cells previously treated with NIC alone or in the presence of $\alpha$-BTX. In the latter case, cells were incubated with $1.5 \mu \mathrm{g} / \mathrm{ml}$ of $\alpha$-BTX for $30 \mathrm{~min}$, then $100 \mu \mathrm{M}$ of NIC was added for $20 \mathrm{~min}$ and finally $10 \mu \mathrm{g} / \mathrm{ml}$ of poly(I:C) for $12 \mathrm{~h}$. Fold-change values compared with the control. Differences were analysed using One-way ANOVA followed by Tukey's post-hoc test. Data represent means \pm SD $(n=4)$. Significant differences between treatments: *, $p<0.05 ; *^{*}, p<0.01 ; * * *, p<0.001$. 
Figure 8. Comparison of the $\alpha$-BTX-binding site and the cytoplasmic domain of the rainbow trout $\alpha 7 n A C h R$ with other species. (A) Comparison of the $\alpha 7 \mathrm{nAChR} \alpha$ BTX-binding site with other sequences. Essential amino acids for $\alpha$-BTX-binding are shown in blue. The amino acid numbering, according to the rainbow trout sequence (Fig. 1), is indicated above. (B) Comparison of the rainbow trout $\alpha 7 \mathrm{nAChR}$ cytoplasmic domain with human $\alpha 7 \mathrm{nAChR}$ cytoplasmic domain. 


\section{Supplementary Material}

\section{Functional evidence for the inflammatory reflex in teleosts: A novel $\alpha 7$ nicotinic acetylcholine receptor modulates the macrophage response to dsRNA}

\footnotetext{
Débora Torrealba ${ }^{\mathrm{a}, \mathrm{b}, 1}$, Joan Carles Balasch ${ }^{\mathrm{b}}$, Manuel Criado ${ }^{\mathrm{c}}$, Lluís Tort ${ }^{\mathrm{b}}$, Simon Mackenzie $^{\text {d, } 2}$ and Nerea Roher ${ }^{\text {a, b, } 2}$

${ }^{a}$ Institut de Biotecnologia i de Biomedicina (IBB), Universitat Autònoma de Barcelona, 08193 Cerdanyola del Vallès, Spain.

${ }^{\mathrm{b}}$ Departament de Biologia Cel·lular, Fisiologia Animal i Immunologia, Universitat Autònoma de Barcelona, 08193 Cerdanyola del Vallès, Spain

c Instituto de Neurociencias, Universidad Miguel Hernández-CSIC, 03550 Sant Joan d’Alacant, Spain.

d Institute of Aquaculture, University of Stirling, Stirling, FK9 4LA, United Kingdom.

${ }^{1}$ Current address: Department of Agricultural, Food \& Nutritional Science, University of Alberta, Alberta, Canada.

${ }^{2}$ Corresponding authors: Nerea Roher, telephone: (34) 935812805; fax: (34) 935812011; e-mail: nerea.roher@uab.cat and Simon Mackenzie, telephone: (44) 01786467992; fax: (44) 01786467852; e-mail: simon.mackenzie@ stir.ac.uk.
} 


\section{Supplemental Table 1. Rainbow trout primers for the cloning of $\alpha 7 n A C h R, q P C R$}

and RT-PCR. Nomenclature of the degenerate primers: Y: C + T; R: A + G and M: A $+\mathrm{C}$.

\begin{tabular}{|c|c|c|c|}
\hline Gene & Primer name & Sequence & Accession $n^{\circ}$ \\
\hline a 7 nicotinic acetylcholine receptor & om_a7ACh_degenerate & $\begin{array}{l}\text { For_CAGATCATGGAYGTGGATGARAMGAA } \\
\text { ReV_CGCTTCATMCGYAGGCCACC }\end{array}$ & \\
\hline a 7 nicotinic acetylcholine receptor & om_ $\triangle 7$ ACh RACE 5 : & $\begin{array}{l}\text { GSP1_GGATITCAGAAGAGAGGGTGACAG } \\
\text { GSP2_ATGCAGCTIIIGATACCT }\end{array}$ & \\
\hline a 7 nicotinic acetyicholine receptor & on_a7ACh_RACE 3 & GSP1_CCGCCTCCAAGGACTTCTTC & \\
\hline a 7 nicotinic acetyicholine receptor & orn_a7ACh & $\begin{array}{l}\text { For_GTGGCTTCGCAGAGTATCTCCC } \\
\text { Rev_GTTGGACATGTACCCGGAGA }\end{array}$ & \\
\hline a) nicotinic acetylcholine receptor & or _a7ACh_Exon 4 & $\begin{array}{l}\text { For_CCAATCTGAATACCCTGGAGTG } \\
\text { ReV_TTGGACATGTACCCGGAGAT }\end{array}$ & \\
\hline a 7 nicotinic acotylcholine receptor: & orn_a7ACh_Exon9 & $\begin{array}{l}\text { For_GGAGAGTGATGACCCAGAGC } \\
\text { Rev_CGATGGTGCAGATGATGTTG }\end{array}$ & \\
\hline a 9 nicotinic acetylcholine receptor & om_aSACh_l & $\begin{array}{l}\text { For_CACTGGGCCAAGGTACTCAT } \\
\text { REV_TGCCTGATAGTCCAGCTCCT }\end{array}$ & AY037940.1 \\
\hline a 9 nicotinic acerylcholine receptor & om_agrch II & $\begin{array}{l}\text { For_CCCTGACTGTCITCCAGCTC } \\
\text { ReV_CTCTGGTGATGTGGTGTIGG }\end{array}$ & AY611482.1 \\
\hline$\alpha 9$ nicotinic acetylcholine receptor & om_a9ACh_III & $\begin{array}{l}\text { For_CCCTGCATGATGATCTCCTT } \\
\text { Rev_CAAGGACTCCCCATTCACAT }\end{array}$ & AY611483.1 \\
\hline Elongation factor $1 \alpha$ & or $\_E F-1$ & $\begin{array}{l}\text { For_CAAGGATATCCGTCGTGGCA } \\
\text { Rev_ACAGCGAAACGACCAAGAGG }\end{array}$ & NM_OO1124339.1 \\
\hline Imterleukin $1 \beta$ & om $1 \mathrm{IL}-1 \beta$ & $\begin{array}{l}\text { For_GGAGGCAGCAGCTACCACAAA } \\
\text { Rev_CCGATTTGGAGCAGGACAGG }\end{array}$ & NM_O01124347.2 \\
\hline Interleskin 6 & orn_It-6 & $\begin{array}{l}\text { For_TTCAGAAGCCCGTGGAAGAGA } \\
\text { Rev_TCTTTGACCAGCCCTAATCAGCA }\end{array}$ & NM_O01124657.1 \\
\hline Tumor necrosis factor $\alpha$ & om_TNF. $a$ & $\begin{array}{l}\text { For_CGCTGACACAGTGCAGTGGA } \\
\text { Rev_TCCCCGATGGAGTCCGAATA }\end{array}$ & NM_001124357.1 \\
\hline Matrix mesalloproteinase 9 & om_MMPg & $\begin{array}{l}\text { For_TTCCAATTCAAGGGCAACTC } \\
\text { Rev_TCAGCCCCCACAGIIAAGAG }\end{array}$ & NM_D01124370.1 \\
\hline Suppressor of cytokine signaling 3 & om_SOCS3 & $\begin{array}{l}\text { For_AACAACACAAGATATCAAGCTCAAG } \\
\text { Rev_GAAGGTCTIGTAACGGTGAGGCAG }\end{array}$ & AM748723.1 \\
\hline Chemokine $(\mathrm{C}-\mathrm{C}$ motid) ligand 4 & on_CCLA & $\begin{array}{l}\text { For_GTGCCATCACTITIACCG } \\
\text { Rev_ACATTTCTTCGGTCCGCTTG }\end{array}$ & NM_001123618:1 \\
\hline Interferon 1 & om IFN1 & $\begin{array}{l}\text { For_GCCCAGTCCTTTTCCCAAC } \\
\text { Rev_CCTCTCAGGTTTCATGGCAGGT }\end{array}$ & AN5\$0911.2 \\
\hline Myxovirus resistance 1 & om_Mxi & $\begin{array}{l}\text { For ATGCCACCCTACAGGAGATGAT } \\
\text { Rev_TGCAGCIGGGAAGCAAACTCC }\end{array}$ & NM_001171901.1 \\
\hline CC Chemokine 6 & Om_CKG & $\begin{array}{l}\text { For_CGAATCTGCTCTGACACTICC } \\
\text { Rev_IGGTGAGITGIIGACCATIGA }\end{array}$ & CA355962.1 \\
\hline Viperin 1 & om_vig & $\begin{array}{l}\text { For_CAGTTCAGTGGCTTTGACGA } \\
\text { REv_ACAAACGCCTCAAGGTATGG }\end{array}$ & AF 076620 \\
\hline Toll like receptor 3 & om_TLR3 & $\begin{array}{l}\text { For_ACGGCTCAACCTGAATATGG } \\
\text { Rev_GCTCTCCAGTGCCCTTAGTG }\end{array}$ & DQ459470 \\
\hline Melanoma differentiation-associated 5 & om_MDA5 & $\begin{array}{l}\text { For_TTTGTGCTGAGCATCTACGG } \\
\text { REv_TTAATGATGGCCTCCTCGTC }\end{array}$ & FN396357 \\
\hline Toll like receptor $8 \mathrm{~b}$ & om_TURBb & $\begin{array}{l}\text { Fot_CATGCAATGTCACCATAGCC. } \\
\text { Rev_CACAACCTTGTGAAGCCAGA }\end{array}$ & GQ422120.1 \\
\hline Cathelicidin 1 & om_CAMP1 & $\begin{array}{l}\text { For_GGCTGACCTTCCCCATACAG } \\
\text { Rev_CAGGTTGTTGCTTGCCTCC }\end{array}$ & NM_001124430.1 \\
\hline
\end{tabular}


Signal peptide

Oncorhynchus mykiss Esox lucius

Takifugu rubripes

Poecilia reticulata

Haplochromis burtoni

Danio rerio

Gallus gallus

Homo sapiens

Mus musculus

Oncorhynchus mykiss

Esox lucius

Takifugu rubripes

Poecilia reticulata

Haplochromis burtoni

Danio rerio

Gallus gallus

Homo sapiens

Mus musculus

Oncorhynchus mykiss

Esox lucius

Takifugu rubripes

Poecilia reticulata

Haplochromis burtoni

Danio rerio

Gallus gallus

Homo sapiens

Mus musculus

Oncorhynchus mykiss

Esox lucius

Takifugu rubripes

Poecilia reticulata

Haplochromis burtoni

Danio rerio

Gallus gallus

Homo sapiens

Mus musculus

Oncorhynchus mykiss

Esox lucius

Takifugu rubripes

Poecilia reticulata

Haplochromis burtoni

Danio rerio

Gallus gallus

Homo sapiens

Mus musculus
MQLFDTFYFCHLSSEIPCSPFPSISLSSVLLSVSVQGPHQRTLLKNLLKDYNRMERPVGN . . . MWCSVALVVCGFSALVQVSEQGPHQRTLLKNLLKDYNRMERPVGN . . . . . . . . . . . . . .................... MWHSVALLLSGLSALINVSLQGPHQRNLLKNLLKDYNRMERPVGN ....... MWHSVALLLSGFSALI HVSLQGPHQRTLLKNLLKDYNHMERPVAN - . . . . MDRVKVETLQPCHIVHSPTVSLQGEHQRRLYRDLMKDYNPLERPVFN MGLQALMLWLLAAAGLVRESLQGEFQRKLYKBLLKNYNPLERPVAN MRCSPGGVWLALAASLLHVSLQGEFQRKLYKELVKNYNPLERPVAN $\ldots$ MCGRRGGIWLALAAALLHVSLQGEFQRRLYKBLVKNYNPLERPVAN

$$
\star \star \star, \star \star \star * ; * ; * ; \star ; * \star \star \star \star \star
$$

Loop D

\section{$\bullet$}

DSHSLTVFFS ISLMQIMDVDEKNOVVTTNIWLRMSWFDHYLOWNOSEYPGVKNL.RFTTDQ DSHPLTVSFTLSL IQIMDVDEKNQ ILTTNIWLRMSWYDHYLQWNQSEYPGVKNLRFTTDQ DSQPLTVVFTLSLIQIMDVDEKNQILTTNIWLRMSWFDHYLQWNQSEHPGVKNLRFTTDQ DSHPLTVFFTLSLIQTMDVDEKNQVLTSNMWLOMSWYDHYLQWNQSDHPGVKNLRFTTDQ DSLPLNVSFSLSLIQIMDVDEKNQVLTSNMWLQMTWYDHYLQWNQSEHPGVKNLRFTTDQ DTHSLTVYFSMSLMQIMDVDEKNQVLTTNIWLQLYWYDYYLQWNASEYPGVTNVRFPDSQ DSQPLTVYFTLSLMQIMDVDEKNQVLTTNIWLQMYWTDHYLQWNVSEYPGVKNVRFPDGL DSQPLTVYFSLNLLQIMDVDEKNQVLTTNIWLOMSWTDHYLQWNVSEYPGVKTVRFPDGQ DSQPLTVYFSLSLLQIMDVDEKNQVLTTNIWLQMSWTDHYLQWNMSEYPGVKNVRFPDGQ

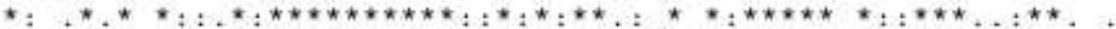
Loop A Loop E Cys-loop

VWTPDILLYNSADDDFDSTFKTNVLVNSSGFAEYLPPGIFMSTCNVDVRWFPFDIQKCEM VWTPDILLYNSADDDFDSSFKTNVLVNSSGPVEYLPPGI FMSTCNVDVRWFPFDIQKCEM IWTPDILLYNSADDDFDSTFKTNVLVNSSGYAEYQPPGIFMSTCNVDVRWFPFDIQRCEL IWTPDILLYNSADDDFDSTFKTNILVNSSGFAKYLPPGI FMSTCNVDVRWFPFDIQKCEL IWTPDILLYNSADDDFDSTFKTNVLVNSSGFAKYLPPGI FMSTCNVDVRWFPFDIQKCEL IWKPDILLYNSADERFDATFHTNVLVNSSGACQYLPPGIFKSTCY IDVRWFPFDLQRCDL IWKPDILLYNSADERFDATFHTNVLVNSSGHCQYLPPGIFKSSCY IDVRWFPEDVQKCNL IWKPD ILLYNSADERFDATFHTNVLVNPSGHCQYLPPGI FKSSCY IDVRWFPFDVQHCKL IWKPDILLYNSADERFDATFHTNVLVNASGHCQYLPPGI FKSSCYIDVRWFPFDVOQCKL

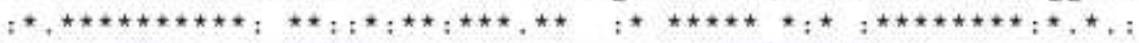
Loop B Loop F Loop C $\bullet *$

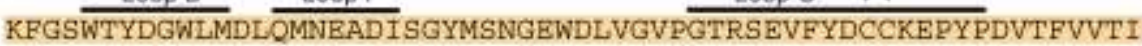
KFGSWTYDGWLMDLQMTDADISGYMSNGEWDLVGVPGTRNEAFYDCCKEPYPDVTFVITI KFGSWTYDGWLLDLOMNEADISGYMANGEWDLIGVPGTRNEVFYDCCKEPYPAVTFVVAI KFGSWTYDGWLLDLQMTDADISGYMPNGEWDLIGVPGSRNEVFYDCCKEPYPDVTFVITI KFGSWTYDGWLLDLOMVDAD ISGYMPNGEWDLIGVPGKRNEVFYDCCKEPYTDVTFVITI KFGSWTYGGWSLDLQMIDADITGYIANGEWDLVEVPGRRNERFYDCCKEPYPDVTFTVVM KFGSWTYGGWSLDLQMQEADISGYISNGEWDLVGIPGKRTESFYECCKEPYPDITFTVTM KFGSWSYGGWSLDLQMQEADISGYI PNGEWDLVGIPGKRSERFYECCKEPYPDVTFTVTM KFGSWSYGGWSLDLQMQEADISSYI PNGBWDLMGI PGKRNEKFYECCKEPYPDVTYTVTM

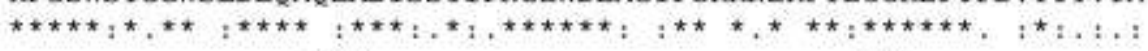
TM1 TM2

RRRTLYYALNLLIPCVLLSSMTLLIFLLPADSGEKISLGITVLLSLTVPMLLVAEIMPAT RRRTLYYALNLLI PCVLLSSMTLLI FVLPADSGEKISLGITVLLSLTVPMLLVAEIMPAT RRRTLYYALNLLIPCVLLSSMTLLIFVLPADSGEKISLGITVLLSLTVFMLLVAEIMPAT RRRTLYYALNLLIPCVLLSSMTLLIFVLPADSGEKISLGITVLLSLTVFMLLVAEIMPAT RRRTLYYALNLLIPCVLLSSMTLLIFVLPADSGEKISLGITILLSLTVFMLLVAEIMPAT RRRTLYYGLNLLIPCVLISTLALLVFLLPADSGEKISLGITVLLSLTVFMLLVAEIMPAT RRRTLYYGLNLLIPCVLISALALLVFLLPADSGEKISLGITVLLSLTVFMLLVAEIMPAT RRRTLYYGLNLLIPCVLISALALLVFLLPADSGEKISLGITVLLSLTVFMLLVAEIMPAT RRRTLYYGLNLLIPCVLISALALLVFLLPADSGEKISLGITVLLSLTVFMLLVAEIMPAT

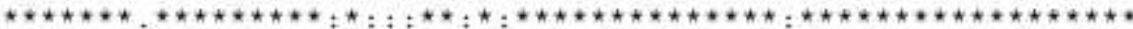


Oncorhynchus mykiss

Esox lucius

Takifugu rubripes

Poecilia reticulata

Haplochromis burtoni

Danio rerio

Gallus gallus

Homo sapiens

Mus musculus

Oncorhynchus mykiss

Esox lucius

Takifugu rubripes

Poecilia reticulata

Haplochromis burtoni

Danio rerio

Gallus gallus

Homo sapiens

Mus musculus

Oncorhynchus mykiss

Esox lucius

Takifugu rubripes

Poecilia reticulata

Haplochromis burtoni

Danio rerio

Gallus gallus

Homo sapiens

Mus musculus

Oncorhynchus mykiss

Esox lucius

Takifugu rubripes

Poecilia reticulata

Haplochromis burtoni

Danio rerio

Gallus gallus

Homo sapiens

Mus musculus

Oncorhynchus mykiss

Esox lucius

Takifugu rubripes

Poecilia reticulata

Haplochromis burtoni

Danio rerio

Gallus gallus

Homo sapiens

Mus musculus
SDSIPLIGQYFASTMI IVGMSVIATTVVLQYHHHDPNGGQMPKWVNVVLLOWVAWFLRMK SDS I PL IGQYFASTMI IVGMSVIATTVVLQYHHHD PNGGQMPKWVNVVLIQWVAWFLRMK SDSVPLIGQYFAS IMI IVGMSVVATVVVLQYHHHDPNGGNMPKWVQLVLLQWVAWFLRMK SDSVPLIGQYFAS IMI IVGMSVIATVVVLQYHHHDPNGGHMPKWVRLVLIQWVAWFLRMK SDSVPL IGQYFASIMI IVGMSVIATVVVLQYHHHDPTGGKMPKWVRLVLLQWVAWFLRMK SDSVPLIAQYFATTMVIVGLSVIATVWVLQYHYHDPEGGKMPKWTRVVLLNWCAWFLRMK SDSVPLIAQYFASTMI IVGLSVVVTVIVLQYHHHDPDGGKMPKWTRVILLNWCAWFLRMK SDSVPLIAQYFASTMI IVGLSVVVTVIVLQYHHHDPDGGKMPKWTRVILLNWCAWFLRMK SDSVPLIAQYFASTMI IVGLSVVVTVIVLRYHHHDPDGGKMPKWTR I ILLNWCAWFLRMK

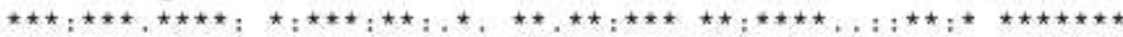
BPGESDDPERPPCAPHTRRCST

RCSSSSQSGSIANPPDPTLHOLHPONLVPLQAGPOHLGHPHL RPGESDDPERPPCAPNLRRCSSSSQSGSI PNPPEPPLHPLHPQNLPPLQAGPLHAGHPHL RPGEKDSPERPPCAPHLRRCSSGSQSGSIPNPPDHALHPLHPQGLA.PLQPGGLHAGQPHV RPGENDDPERPPCAPHLRRCSSGSQSGSIPNPPDPTLHPLHPQNLTPLOTGPLHAGHPHL RPGESDDPERPPCAPHLRRCSSGSQSGSI PNPPD-SLHPLHPQNLAPLQTGPLHAGHPHL RPGE- -DKVRPACHNKQPRSSLSSVDLNISPGVAQS RPGE - DKVRPACQHKQRRCSLSSMEMNTVSGQQCS RPGE- -DKVRPACQHKQRRCSLASVBMSAVAPPPAS $\ldots \ldots \ldots$ RPGE--DKVRPACQHKPRRCSLASVELSAGAGPPSS $\ldots \ldots \ldots$ $* \star \star \star * * * *$ : **.*..

HAQSSANNNGNLLYIGFQNLDDPPLLPDHIQNYSISAGPPRVAGSPPPHLPPPFCSPPPP HAQSSAXNNGNLLYIGFQNLDDPPLLPEHIPRNSI SAGPPRVAGSPPPHLPPQFCSSSPP HAQS SANNNGNLVYLGFQSVEDSAGLPEPIQRNNISTGPPRVAGSPPPHLPSQFCSSPPP - - QTSANNNGNLL YMGFPS IEDSSVLSEPVQRNNI SVGPPRVAGSPPPHLPSQFCSSPPP QAQTSANNNGNLLYMGFQSMDDPSVLPESIQRNNISAGPLRVAGSPPPHLPSQFCSSPPP QA.

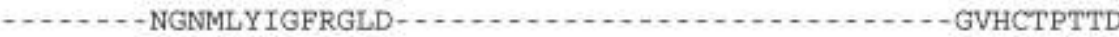
.

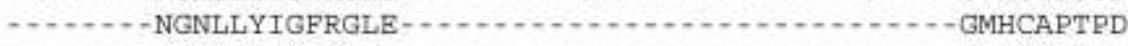
$\star \star \star ;: \star ; \star \star \star \quad ; ;$

PTPNADTVGCPSTISSGGVFGMGGG --GQYSAGRIGDPQLQAILEEVRYMADRFREQDET PTVNADTVGCPSTVSSGGGFGMGAG - -GQCSSGVI GDPQLQAILEEVRYMADRFREQDET PASNMDT-GCPSTVSSGGGFGGGGGGLGGCSASAVGDPQLHAILEEVRFVADREREQDEV PTPNMDTVGCPSTVSSGGGFGGGP - - - GGCSTSVMGDPQLQAILEEVRYMADRFREQDET PTPNVETVGCPSTVSSGGGFGGGAGGLGGCSTVGMGDPQLQAILEEVRYMADRFREQDET SGVICSRL-VATGEEDVLLPGAQA---SSVSSSGPGETELSKILDEVRYISKRFRDQDEB SGVICGRMTCSPTEEENLLHSGHP ........ SEGDPDLAKILEEVRY IANRFRDQDEB SGVVCGRMACSPTHDEHLLHGGQP ........ PEGDPDLAKILEEVRYIANRFRCQDES SGVVCGRLACSPTHDEHLMHGTHP-.......-SDGDPDLAKILEEVRYIANRFRCQDES

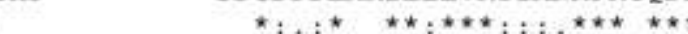

\section{TM4}

ESVADQWKFAAAVIDRLCLVAFSVFNI ICTIAILMSAPNFVEAASKDFFESTADQWKFAASVIDRLCLVAFSVFNI ICTIAILMSAPNFVEAASKDFFSGAADQWKFAGAVIDRLCLVAFSVFNI ICTISILMSAPNFVEAISKDFV ESMADQWKFAGAVIDRLCLVAFSVFNI ICTISILMSAPNFVDAISKDFVBSMAEQWKFAGAVIDRLCLVAFSVFNI ICTISILMSAPNFADAISKDFV DTVCNEWKFAASVIDRLCLMAFSLFTILCTIGILMSAPNFVEAISKDEFT BAICNEWKFAASVVDRLCLMAFSVETI ICTIGILMSAPNFVEAVSKDFAEAVCSEWKFAACVVDRLCLMAFSVFTI ICTIGILMSAPNFVEAVSKDFAEVICSEWKFAACVVDRLCLMAFSVETIICTIGILMSAPNFVEAVSKDFA-

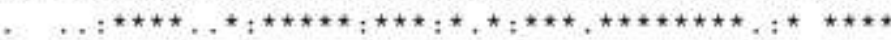




\section{Supplemental Figure 1. Alignment of $\alpha 7 \mathrm{nAChR}$ protein sequences from different}

species. In the alignment are shown: fully conserved amino acids $(\star)$, cysteines

forming disulfide bonds in the binding site and, the putative glycosylation $(\bullet)$ and phosphorylation sites ( $\mathbf{\square}$ ). Bars above the alignment indicate the signal peptide, the ACh-binding site loops (A, B, C, D, E and F), Cys-loop and the transmembrane regions (TM1 - TM4). The shaded areas of the $O$. mykiss $\alpha 7 \mathrm{nACh}$ receptor sequence show the neurotransmitter ion channel ligand-binding domain (light orange) and the transmembrane region (light green).

Supplemental Figure 2. (A) Exon-intron boundaries of the rainbow trout $\boldsymbol{\alpha} 7 \mathbf{n A C h R}$ gene. Exon sequences are indicated by uppercase letters and intron sequences by lowercase letters. Splice donor and acceptor sites are indicated in bold. Exon and intron sizes are reported as base pairs (bp). (B) Exon diagrams of the $\alpha 7 n A C h$ gene in rainbow trout and other species.

A

\begin{tabular}{ccccc}
\hline \multicolumn{5}{c}{ Sequence at exon-intron boundaries } \\
\hline Exon $\mathbf{n}^{\circ}$ & Exon size (bp) & 5 splice donor & 3'splice acceptor & Intron size (bp) \\
\hline 1 & 237 & GGATGTGGtagggatc & atcttacaGGATGAGA & 211 \\
2 & 45 & TCGGATGGtaagcacg & gtcttccaGAGCTGGT & 668 \\
3 & 110 & ATAACAGGtaatacac & cgttaaaaGTGCAGAT & 457 \\
4 & 80 & TTTCCACGtctgtta & gtctgttaGGGATTT & 990 \\
5 & 168 & CTAGTGGGtcagtggg & tctctcaaGGAGTGCC & 127 \\
6 & 195 & TCTCTGGGtgagcaga & tctttcaGGTATCAC & 1750 \\
7 & 87 & CTCATAGGtgtgtgtt & accttcaGGACAGTA & 341 \\
8 & 110 & CAAATGGGtaaggcca & tccttcaGGTTAATG & 4101 \\
\hline
\end{tabular}

B

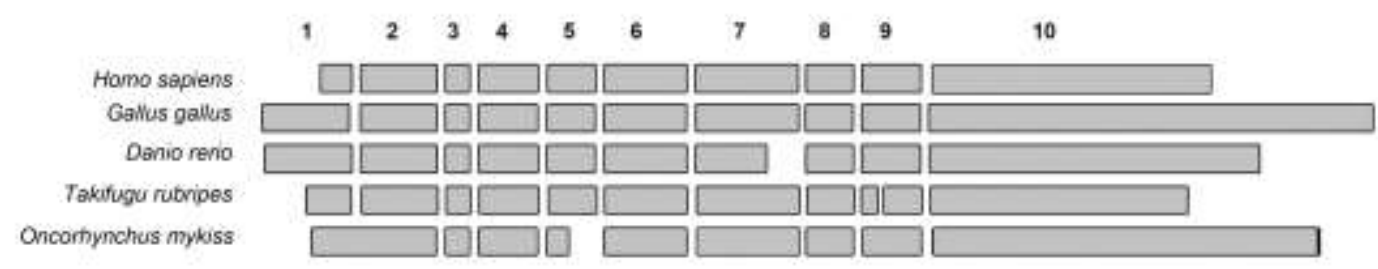



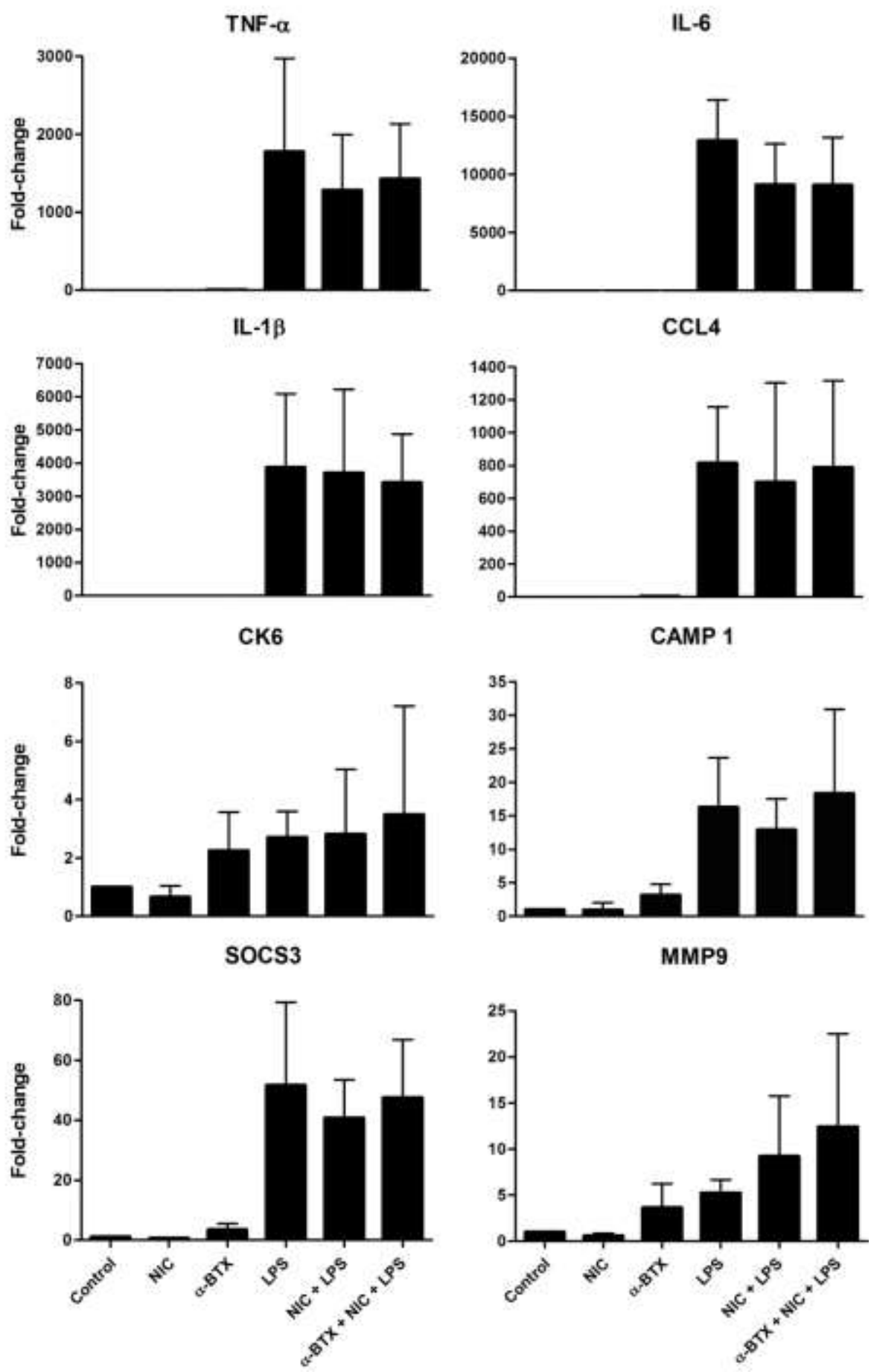

Supplemental Figure 3. Gene expression analysis in HKM cells stimulated with NIC and $\alpha$-BTX prior to stimulation with LPS. Cells were incubated with $1.5 \mu \mathrm{g} / \mathrm{ml}$ of $\alpha$-BTX for $30 \mathrm{~min}$, then $100 \mu \mathrm{M}$ of NIC was added for $20 \mathrm{~min}$ and finally $10 \mu \mathrm{g} / \mathrm{ml}$ of LPS for $12 \mathrm{~h}$. The gene expression was analysed by qPCR. Data represent means \pm $\mathrm{SD}(n=4)$. 
A

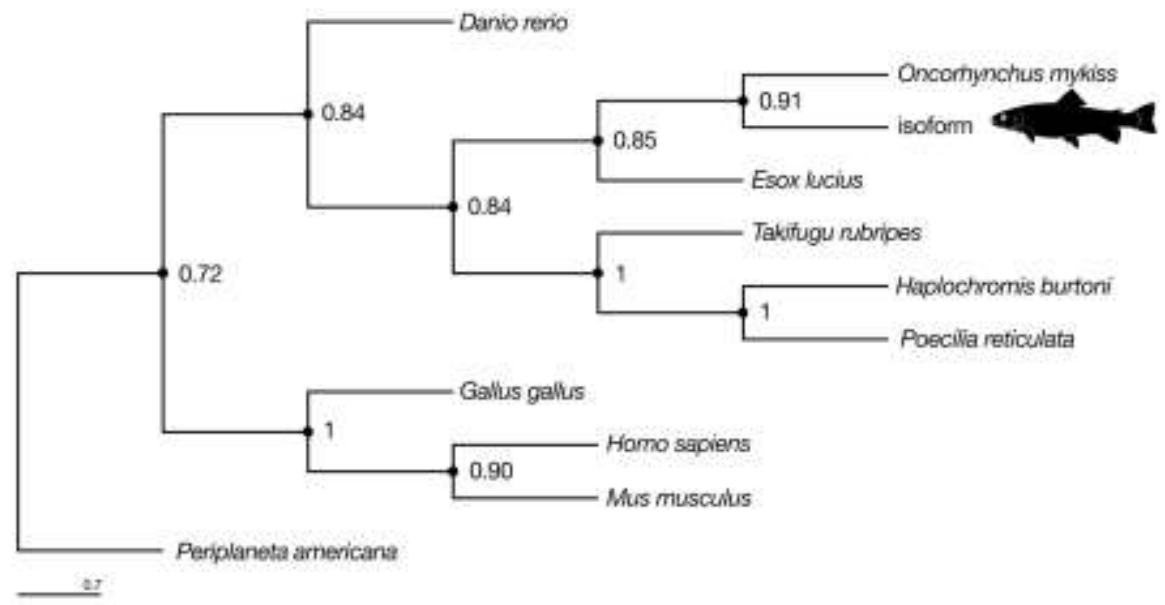

B

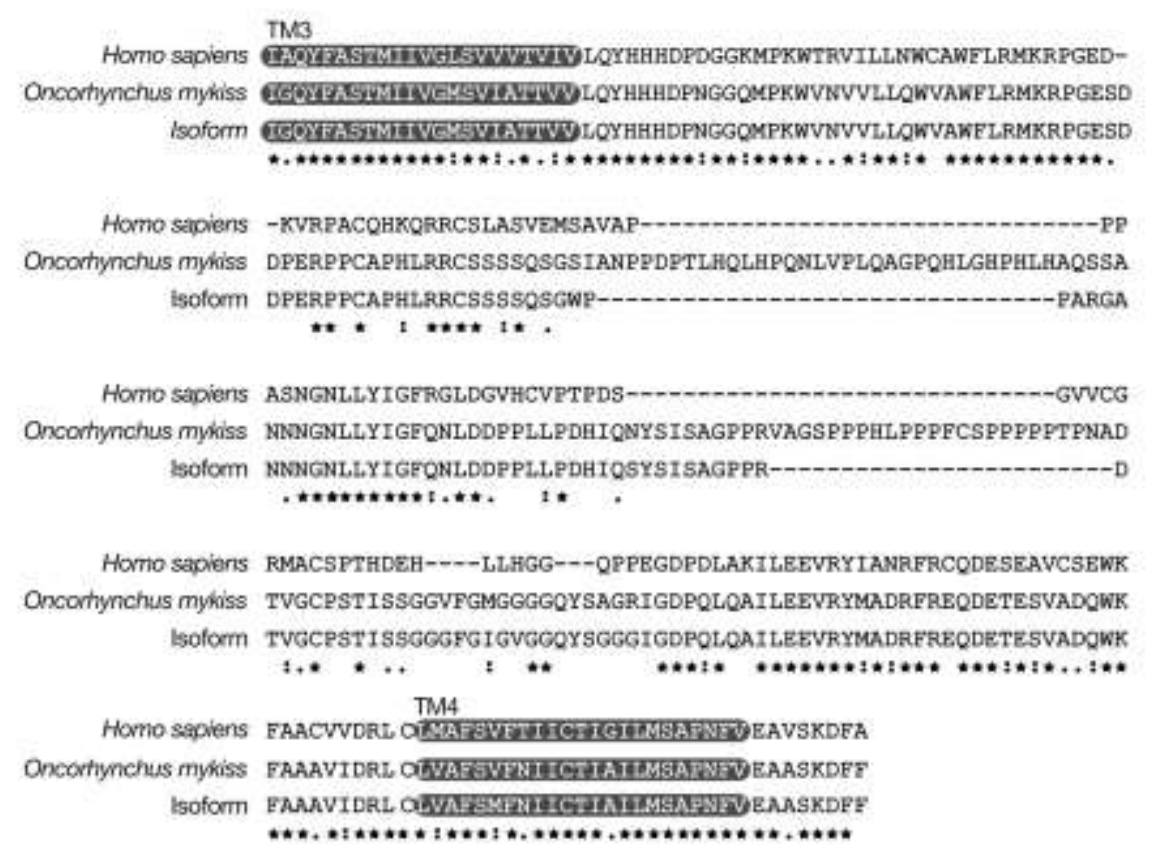

Supplemental Figure 4. (A) Phylogenetic relationships of rainbow trout $\alpha 7 \mathrm{nACh}$ isoform receptor with other species. Branching values are the maximum likelihood percentage of majority rule extended consensus bootstrapped trees and Bayesian posterior probabilities, respectively. Periplaneta americana was chosen as the outgroup. The bar indicates the phylogenetic distance. (B) Comparison of the $\alpha 7 \mathrm{nAChR}$ cytoplasmic domain between O. mykiss (KT634308); H. sapiens (AF385585.1) and isoform (CDQ72725). In the alignment are shown fully conserved amino acids $(\star)$. Grey bars in the alignment indicate transmembrane regions (TM3 - TM4). 


\section{Supplemental Methods}

\section{Genomic DNA structure and exon-intron boundary analyses}

The initial gene structure was analysed by comparing the $\alpha 7 \mathrm{nAChR}$ coding sequence with the rainbow trout genome draft (Palti et al., 2012) available at the National Animal Genome Research Program (NAGRP, 2013). The DNA sequence and the cDNA of the $\alpha 7 \mathrm{nAChR}$ were aligned both manually and using the Spidey software. The exon/intron boundaries were determined with Splice site prediction and NetGene 2 Server. We also performed genomic DNA extraction to further analyse the undefined exon-intron sequences. The genomic DNA (gDNA) from rainbow trout brain tissue was obtained using a standard phenol-chloroform extraction protocol (Sambrook et al., 1989) and the DNA was quantified using a Nanodrop ND-1000. RT-PCR was carried out with $100 \mathrm{ng}$ of gDNA using specific primers (Supplemental Table 1) and the amplified fragments were sequenced.

\section{Supplemental References}

NAGRP, 1998. National Animal Genome Research Program. NRSP-8 Bioinformatics Coordination Program. Salmonids Genomics. http://www.animalgenome.org /aquaculture/salmonids/. Accessed on October 24, 2013.

Palti, Y., Genet, C., Gao, G., Hu, Y., You, F.M., Boussaha, M., Rexroad, C.E., Luo, M.C., 2012. A Second Generation Integrated Map of the Rainbow Trout (Oncorhynchus mykiss) Genome: Analysis of Conserved Synteny with Model Fish Genomes. Mar. Biotechnol. 14, 343-357.

Sambrook, J., Fritsch, E., Maniatis, T., 1989. Molecular cloning: a laboratory manual. Cold Spring Harbor Laboratory Press, New York, 545. 